\title{
Dogs in Jewish Society in the Second Temple Period and in the Time of the Mishnah and Talmud ${ }^{1}$
}

\author{
JOSHUA SCHWARTZ \\ Bar-Ilan University
}

Introduction

\section{The Biblical World}

B ased on what is related in the Bible, dogs were not afforded a great deal of respect or affection in Israelite or Judahite society in the Land of Israel. $^{2}$ The term 'dog' was considered a derogatory appellation (I Sam. 17:43), the wording 'dead dog' (I Sam. 24:15; II Sam. 9:8; 16:9) expressed humiliation and contempt, and the term 'dog's head' (II Sam. 3:8) apparently had a negative connotation. ${ }^{3}$

Nor did the dog's usefulness significantly improve its image, even though the dog had already been domesticated in the Ancient Near East in the Mesolithic era (15,000-8,000 BCE),${ }^{4}$ and from then on had been trained for

\footnotetext{
1 This essay marks the culmination of several years of study of the subject of dogs, conducted within the context of my research project, 'Leisure-Time Activities in Ancient Jewish Society.' The initial plan of this study called for an examination of dogs as pets, corresponding to the focus of the 'Leisure-Time Activities' project, but as the work progressed, it became clear that this subject required a more general study of the dog in Jewish society in antiquity. I have published several preliminary essays on this subject, with their findings summarised in the current article. See my previous publications on the dog in Jewish society: J. Schwartz, 'Dogs and Cats in Jewish Society in the Second Temple, Mishnah and Talmud Periods', Proceedings of the Twelfth World Congress of Jewish Studies, Division B: History of the Jewish People (Jerusalem, 2000), pp. 25*_ 34*; idem, 'Dogs, "Water" and Wall', Scandinavian Journal of the Old Testament 14 (2000), pp. 101-16; idem, 'Dogs in Ancient Jewish Rural Society', in A. M. Maeir, S. Dar and Z. Safrai (eds), The Rural Landscape of Ancient Israel (Oxford), British Archaeological Reports, International Series, 1121 (2003), pp. 127-36. A parallel study on cats has been published as 'Cats in Ancient Jewish Society', in JJS, 52 (2001), pp. 211-34.

${ }^{2}$ For the dog in the Biblical period, see: E. A. Goodfriend, 'Could keleb in Deuteronomy 23:19 Actually Refer to a Canine', in D. P. Wright, D. N. Freedman and A. Hurvitz (eds), Pomegranates and Golden Bells: Studies in Biblical, Jewish, and Near Eastern Ritual, Law and Literature in Honor of Jacob Milgrom (Winona Lake, IN, 1995), pp. 381-97, and the bibliography ad loc. See also: D. Winton Thomas, 'Kelebh "Dog": Its Origin and Some Usages of It in the Old Testament', VT 10 (1960), pp. 410-27. Cf.: E. Firmage, 'Dogs', The Anchor Bible Dictionary 6, cols. 1143-44; O. Borowski, Every Living Thing: Daily Use of Animals in Ancient Israel (Walnut Creek, CA, London, and New Delhi, 1998), pp. 133-40. Goodfriend maintains, as do the Rabbis, that the word kelev in Deut. 23:19 is to be interpreted literally: 'the pay of a dog', and disagrees with the understanding of some modern commentators, that this term refers to a male prostitute. This is prohibited because the dog symbolises the antithesis of all that is considered holy in the Biblical tradition. Cf. below, for the Rabbinic understanding of the term.

3 See Goodfriend, 'Could keleb in Deuteronomy 23:19', p. 389 nn. 35-36.

${ }^{4}$ Current discussions of the source and domestication of the dog appeared in Science, December 2002. See: E. Pennisi, 'Canine Revolution: A Shaggy Dog History', Science 298 (December 2002), pp. 1540-42 (www.sciencemag.org/cgi/content/full/298/5598/1540); P. Savolainen et al., 'Genetic Evidence for an East Asian Origin of Domestic Dogs',
} 
many tasks, such as hunting and guarding. ${ }^{5}$ Biblical literature preferred to describe the dog especially as an urban predator that eagerly devoured carcasses and licked blood (I Kings 14:11; 16:4; $21: 19,24 ; 22: 38) .{ }^{6}$ The inhabitants of cities in the Land of Israel were probably accustomed to the spectacle of famished dogs roaming about at night, barking and howling, in their search for food (Ps. 59:7, 15), ${ }^{7}$ or the sight that was the basis of the metaphor: 'as a dog returns to its vomit' (Prov. 26:11). ${ }^{8}$ Such dogs were liable to attack humans (Ps. 22:17, 21), and the careless individual who drew too close, even if he or she showed affection to these creatures, ${ }^{9}$ would frequently be attacked or

ibid., pp. 1610-13 (www.sciencemag.org/cgi/content/full/298/5598/1610); J. Leonard et al., 'Ancient DNA Evidence for Old World Origin of New Dogs', ibid., pp. 1613-16 (www.sciencemag.org/cgi/content/full/298/5598/1613); B. Hare et al., 'The Domestication of Social Cognition in Dogs', ibid., pp. 1634-36 (www.sciencemag.org/cgi/content/full/298/5598/1634). Savolainen et al. argued that the dog was domesticated in western China some 15,000 years ago. On the other hand, 12,000-year-old graves shared by humans and dogs, that are earlier than the remains discovered in China, were uncovered in the northern Land of Israel (S. J. M. Davis and F. R. Valla, 'Evidence for Domestication of the Dog 12000 Years Ago in the Natufian of Israel', Nature 276 [1978], pp. 608 ff.; E. Tchernov and F. R. Valla, 'Two New Dogs, and Other Natufian Dogs, from the Southern Levant', Journal of Archaeological Science 24,1 [1997], pp. 65-95. It should be noted that it is not commonly accepted that the remains discovered in the Land of Israel graves are of dogs, and not of small wolves, nor are we certain that they were domesticated. See: D. Brewer, T. Clark and A. Phillips, Dogs in Antiquity: Anubis to Cerberus, The Origins of the Domestic Dog [Warminster, 2001], p. 23). For the process of canine domestication, see: F. E. Zeuner, A History of Domesticated Animals (New York and Evanston, 1963), pp. 79-111; J. Clutton-Brock, Domesticated Animals from Early Times (London, 1981), pp. 34-45; idem, 'Origin of the Dog: Domestication and Early History', in J. Serpell (ed.), The Domestic Dog: Its Evolution, Behaviour and Interaction with People (Cambridge, 1995), pp. 7-20; idem, 'Introduction', in: S. J. Crockford (ed.), Dogs Through Time: An Archaeological Perspective, British Archaeological Reports, International Series, 889 (Oxford, 2000), pp. 3-7; S. Bodenheimer, Animal Life in Palestine (Jerusalem, 1956), vol. 2, pp. 331-39 ('The Dog, Man's Earliest Companion') (in Hebrew). Cf. T. Dayan and E. Galili, 'A Preliminary Look at Some New Domesticated Dogs from Submerged Neolithic Sites off the Carmel Coast', in Crockford, Dogs Through Time, pp. $29-33$.

5 See Job 30:1: 'my sheep dogs'. For the adaptation of dogs for such tasks, see esp.: Schwartz, 'Dogs, "Water" and Wall', pp. 101-16; Hare et al., 'Domestication of Social Cognition'. According to Borowski (Every Living Thing, p. 147 n. 4), at least some of the dogs whose remains were discovered at Iron Age sites, such as Tel Michal, Beersheva, and 'Izbet Sartah, were sheepdogs. Despite the positive function of dogs of this type, the term in Job 30:1 has a negative connotation. Cf. Isa. 56:10-11; Borowski, op cit., p. 141, for dogs who herded pigs.

${ }^{6}$ See II Kings 9:35-36; but also see Ex. 22:30. The throwing of flesh from carcasses to a dog may possibly refer to the reality that existed in open country, and not in a settlement; while according to Goodfriend ('Could keleb in Deuteronomy 23:19', pp. 391-92), the reference is to herding dogs.

7 See Clutton-Brock, Domesticated Animals, p. 39. Since the many diverse sounds made by dogs are usually those of domesticated dogs, and not wild ones, some scholars preferred to render yehemu (יהמו) ('They come each evening yehemu (יהמו) like dogs, roaming the city') as snarling, and not as barking or whining. See M. E. Tate, World Bible Commentary, 20: Psalms 51-100 (Waco, TX, 1990), p. 93.

8 For this verse, see T. Forti, 'Animals in the Book of Proverbs', in O. Rimon and R. Schchori (curators), 'Couched as a lion ... who shall rouse him up' (Genesis 49:9): Depictions of Animals from the Leo Mildenberg Collection (Haifa, 1999), p. 60*.

9 Forti, op cit., p. 60*. Holding the dog's ears (or, according to the Septuagint, his tail) was considered to be foolish teasing. 
bitten (Prov. 26:17). There is no suggestion in Biblical literature that dogs were thought of as pets, or that they received any special treatment.

The attitude of the non-Jewish peoples in the Land of Israel and in the surrounding lands was ambivalent. ${ }^{10}$ On the one hand, the dog may have enjoyed a certain sanctified status in the Canaanite cult, ${ }^{11}$ the Hittites even used puppies in purification and healing rites, reminiscent of the connection between the dog and the Babylonian goddess of healing GU-LA, ${ }^{12}$ and there are indications that dogs were kept as pets in some lands of the Ancient Near East in those periods. ${ }^{13}$ There are also many traditions in the Ancient Near East, on the other hand, of the impurity of the dog and its contemptible status, ${ }^{14}$ and even of their ritual use in ceremonies, based on this impurity, in which the dog draws to it uncleanness from a human being. In other instances, dogs were utilised in various rites because they were not needed for anything else. ${ }^{15}$ To the extent that these concepts were known among the Israelites, the general standing of dogs in these cultures, for better or for worse, undoubtedly exerted a negative influence upon Israelite society. Thus, the ritual use of dogs, for whatever reason, would have produced a negative response among the

${ }^{10}$ For the first dogs in Biblical lands and the various types of dogs found there, see Brewer, Clark and Phillips, Dogs in Antiquity, pp. 49-53, 55-71. Based on the art and bone finds, there apparently were five breeds of dogs in the region: mastiff, sheepdog, Canis familiaris, hunting dogs (such as the Saluki), and terrier. Additional types and breeds entered the region over the course of time.

11 See e.g. L. Stager, 'Why Were Hundreds of Dogs Buried at Ashkelon?' Biblical Archaeology Review, 17.3 (1991), pp. 26-42 and the literature listed there. Stager draws a connection between the burial of hundreds of dogs at Ashkelon in the Persian period and the rite of the Canaanite god Resheph, but he offers no proof for such a theory. See P. Wapnish and B. Hesse, 'Pampered Pooches or Plain Pariahs? The Ashkelon Dog Burials', Biblical Archaeologist, 56.2 (1993), pp. 55-80. Stager also proposes seeking a link to the Phoenician god of healing. For the connection between the dog and healing rites, see below. A Ugaritic myth tells of the banquet of a god, the father of the Canaanite gods, in which the dog played an important role, the nature of which, unfortunately, has not been determined. See: M. A. Pope, Anchor Bible: Song of Songs (Garden City, NY, 1977), p. 211. For the ritual interment of a puppy in Philistine Ekron, see: T. Dothan, 'Bronze and Iron Objects with Cultic Connotations from Philistine Temple Building 350 at Ekron', IEJ 52 (2002), p. 22. For the cult of dog sacrifice, the eating of the bodies, and the burial of the bones in the Arabian peninsula, all out of appreciation for the dog as man's faithful friend, see Brewer, Clark and Phillips, Dogs in Antiquity, pp. 53-54.

12 See: B. J. Collins, 'The Puppy in Hittite Ritual', Journal of Cuneiform Studies 42.2 (1990), pp. 211-26; Brewer, Clark and Phillips, Dogs in Antiquity, pp. 54-55. See also B. Halpern, 'The Canine Conundrum of Ashkelon: A Classical Connection', in L. Stager, J. A. Greene and M. D. Coogan (eds), The Archaeology of Jordan and Beyond: Essays in Honor of James A. Sauer (Winona Lake, Indiana 2000), pp. 133-44, who sees a connection between GU-LA, Aesculapius, and Ashkelon. The dog is also linked to many aspects of sorcery; e.g. an ancient Babylonian poem prescribes the throwing of a piece of bread to a dog, in addition to the recitation of a magical incantation, in order to quiet a crying baby. See S. Shifra and J. Klein, In Those Distant Days: Anthology of Mesopotamian Literature in Hebrew (Tel Aviv, 1996), pp. 613-14 (in Hebrew).

13 Borowski, Every Living Thing, pp. 136-37; Brewer, Clark and Phillips, Dogs in Antiquity, pp. $53-54$.

14 Chicago Assyrian Dictionary, vol. 8, cols. 68-73, s.v. 'kalbu'. For the burial of canine idols by the threshold of the house as a charm against spirits, demons, and other destructive entities, see Brewer et al., op. cit., p. 65.

15 Collins, 'The Puppy in Hittite Ritual'. 
Israelites, and the traditions of the disdain in which canines were held by some of the peoples would have been thoroughly understood by them.

The situation was completely different only in ancient Egypt, where dogs were venerated, and where tens of thousands of these animals were mummified. ${ }^{16}$ It is doubtful, however, whether this attitude had a positive effect on the standing of canines among the contemporary Israelites. Generally speaking, the predominant attitude toward dogs in the Ancient Near East, both among the Israelites and the surrounding peoples, was negative. ${ }^{17}$

\section{Man's Best Friend}

As long as Jewish tradition drew from the societies of the Ancient Near East, whose negative attitude regarding dogs was often balanced by cultic applications, whether for positive or negative reasons, no fundamental change could be expected in Israel's basic attitude toward the dog. Significant changes, however, in the prevalent disposition toward dogs began in the Hellenistic period. The Graeco-Roman world's fondness for dogs - the dog became man's best friend ${ }^{18}$ - could have influenced the attitude held by Jews in the Land of Israel and in the Diaspora, and similarly the prevailing mood in the Persian world, as well, in which dogs were appreciated and even the subject of adoration. This article will seek to examine the approach of Jewish society in the Second Temple period and in the time of the Mishnah and Talmud to this creature, one of the most popular in many of the world's societies. ${ }^{19}$ Such an investigation will contribute to our understanding of the attitude of Jewish society in antiquity to the animal world in general, and will add an additional stratum to the various recent attempts to comprehend the everyday life of the Jewish people in ancient times. ${ }^{20}$

16 See Brewer et al., op. cit., pp. 28-48. Egyptian art contains portrayals of both long-limbed (tsm, Saluki) and short-limbed breeds (different types of the mastiff). Dogs were popular as pets and as hunting dogs; they were also used as guard dogs, and even in the service of the police. Despite their affection for dogs, the Egyptians, as well, were nonetheless revolted by the pariah dogs that roamed about in village and city. Dogs were present in Egypt as early as the Neolithic period; already domesticated, they were first used as guard dogs, and only later for hunting.

17 See A. H. Brodrick, Animals in Archaeology (London, 1972), p. 109.

18 Cf., in contrast, the sentiment expressed by Yehuda Amichai: 'Like wolves coming to wail about dogs that became the servants of men' (Y. Amichai, Tzipor ha-Even: Shirim, 1948-1962 [Jerusalem, 1962], p. 19), who mourns the dog's loss of wildness (symbolising freedom).

19 See e.g. F. Mery, The Life, History, and Magic of the Dog (New York, 1968). This phenomenon exists in almost every period. See e.g. R. H. A. Merlen, De Canibus: Dog and Hound in Antiquity (London, 1971); or S. Feeke (ed.), The Dog in Eighteenth and Nineteenth Century Sculpture (Leeds, 2000). Cf. M. E. Thurston, The Lost History of the Canine Race (Kansas City, 1996), who maintains that, despite the dog's great popularity, archaeological sites of importance for canine research or various documents that could contribute to the study of this creature were frequently not preserved or examined.

20 The current research is not limited to a discussion of the place of the dog solely as a pet, and includes all the aspects of the dog's position in the Jewish world during antiquity. 


\section{Greece, Rome and Persia}

\section{The Greeks}

Dogs were quite popular in the Graeco-Roman world. ${ }^{21}$ The Greeks might not have been especially attached to pets, but dogs (and horses) were exceptions in the Greek world in this respect, and the Greeks exhibited quite a bit of affection and sentimentality towards their dogs. ${ }^{22}$ On occasion they even erected funerary monuments in memory of the canine deceased, with the appropriate tombstone inscriptions. ${ }^{23}$ In the Greek world, the dog was considered to be a faithful friend of both the distinguished members of society and of the common people, of men and women, of adults and children. ${ }^{24}$ Dogs frequently accompanied their masters on various errands, to work, to school (waiting outside), to the palaestra, and at times, even to the grave. ${ }^{25}$ Not surprisingly, therefore, dog bones, probably of pets, were found in Greek tombs. ${ }^{26}$ The Greeks also had hunting dogs, sheep dogs, and guard dogs; ${ }^{27}$ dogs were

21 See Brewer, Clark and Phillips, Dogs in Antiquity, pp. 83-102, esp. 84, for 'canine literature' in the Graeco-Roman world. For a detailed list of the various breeds in the Graeco-Roman world, see idem, p. 103; some of them are known only from literature, and therefore we do not know how they looked, or if they actually existed. See also S. Menache, 'Dogs in Classical Tradition', in Rimon and Schchori, 'Couched as a lion', pp. 63*-67*.

22 See Brodrick, Animals in Archaeology, loc. cit. The fixed motif that appears in ancient art is that of the dog lying under the table or couches of the participants in a feast, eating the scraps that fell or that were given directly by the good-hearted diners. See e.g. the illustrations in Pope, Song of Songs, pp. 212, 215. Patroklos, the friend of Achilles, had nine 'table dogs', who probably received scraps from the diners. As a sign of Patroklos' great affection for his dogs, Achilles had two of them slaughtered and placed by their master during the latter's funeral; they were burnt together with their master Patroklos on his funeral pyre (Iliad 23:172-74).

${ }_{23}$ See W. F. Gosling, 'Pets in Classical Times', Greece and Rome 4 (1934/35), pp. 109-10.

24 The classic depiction is that of Argos, Odysseus' dog, who recognised his master after the latter's return home following an absence of twenty years, despite his beggar's garb. Argos became excited upon hearing his master's voice, and then died. Odysseus' son Telemachos also possessed faithful dogs who ate scraps from his table. Greek tradition speaks of additional dogs who were loyal to renowned masters, such as the dog of Xanthippus (the father of Pericles), or that of Alcibiades. See Gosling, 'Pets in Classical Times'. Greek art, as well, frequently depicted dogs as the companions of adults and the pets of children; see Mery, Life, History, and Magic, p. 39. Cf. S. Klinger, 'Animals in Greek Art', in Rimon and Schchori, 'Couched as a lion', pp. 25*-31*; see also Brewer, Clark and Phillips, Dogs in Antiquity, pp. 86-87. Despite all this, the Greeks also realised that the dog was still just a dog, that at times possessed bad qualities, just like humans, and the Greeks sometimes used the imagery of such negative traits to reflect the evil in man. Cf. Menache, 'Dogs in Classical Tradition'.

25 F. A. G. Beck, Album of Greek Education: The Greeks at School and at Play (Sydney, 1975), p. 49; Gosling, 'Pets in Classical Times', pp. 109-10; M. Golden, Children and Childhood in Classical Athens (Baltimore, 1990), p. 125. See also above, n. 22, for the dogs of Patroklos.

26 D. C. Kurtz and J. Boardman, Greek Burial Customs (London, 1971), p. 215. The bones of other pets, such as birds and small pigs, were also discovered.

27 See: Brewer, Clark and Phillips, Dogs in Antiquity, pp. 87-95; Mery, Life, History, and Magic, pp. 36-42. For hunting dogs and the special trappings they required, see D. B. Hull, Hounds and Hunting in Ancient Greece (Chicago and London, 1964), esp. pp. 9-10, 18-19, 20-38. Cf. also A. A. Phillips and M. M. Wilcock, Xenephon and Arrian on Hunting (Warmister, 1999), pp. 6-18, for scent hounds (dogs that use their sense of smell for tracking) and sight hounds (dogs that use their sense of sight for similar ends); and esp. pp. 12-18 for classical breeds. See esp. the detailed table on p. 17, which delineates the different approaches regarding the proper colour for the sheepdog. 
harnessed to small toy carts, and at times were trained to amuse their owners, or even crowds of spectators. ${ }^{28}$

Dogs also had a role in some of the Greek cults. Thus, dogs were presumably blessed with healing power in their tongues, were linked to the rites of Asclepius, the god of healing, and frequently wandered about in the temples of this god. ${ }^{29}$ They were also connected to the rite of the goddess Artemis, and were offered as sacrifices in her honour. Young Spartans sacrificed dogs to the god of war Ares. ${ }^{30}$

\section{The Romans}

The Romans were 'mad' about dogs, and all the above manifestations of affection toward canines in the Greek world were also to be found here, in even more emphatic fashion, thus explaining the presence almost everywhere of dogs of all the types mentioned above. ${ }^{31}$ Romans' ties with their dogs as a companion or pet also were often extremely intense. ${ }^{32}$

Roman children were especially attached to their dogs, played with them, imitated them in their games (in their absence as well), and sometimes refused to part with their beloved dogs even in death, with various scenes portraying 'a child with his dog' inscribed on their coffins. ${ }^{33}$ A special or exceptional dog could even enhance a youthful Roman's prestige among his peers. ${ }^{34}$

The Romans favoured dogs of all breeds and all sizes, while Roman matrons were especially fond of Maltese lap dogs. At times, men, too, fashioned bonds to this small breed of dog, such as the poet Martial, who was brokenhearted at the passing of his Maltese dog, Issa, and composed a poem in her

${ }^{28}$ See, for example, Beck, Album of Greek Education, p. 49. For carts of this type, see J. Schwartz, “'A Child's Cart": A Toy Wagon in Ancient Jewish Society', Ludica, 4 (1998), pp. $7-19$, esp. p., Fig. 6.

29 J. Serpell, In the Company of Animals: A Study of Human-Animal Relationships (Oxford, 1986), pp. 175-76. Cf. Collins, 'The Puppy in Hittite Ritual', p. 214; cf. also Plutarch who tells of the use by the Greeks of puppies in different medicinal ceremonies; for example, these pups would be passed over the afflicted body-parts of the patient, in order to transfer the illness from the sick human to the animal. See: Plutar. Quaest. Roman 68. Pliny describes the holding of puppies above the stomach, intestines, and other parts of the patient: the dogs died, and the sick person recovered. See: Nat. Hist. 30.42-43; 30.64. For a complete list of the maladies that could be healed by the use of live dogs or their excrement, see: E. E. Burris, 'The Place of the Dog in Superstition as Revealed in Latin Literature', Classical Philology 30 (1935), pp. 32-42.

${ }^{30}$ For these rites, see R. E. Bell, Dictionary of Classical Mythology, Symbols, Attributes and Associations (Oxford and Santa Barbara, 1982), p. 68.

31 See J. M. C. Toynbee, Animals in Roman Life and Art (Baltimore and London, 1973), pp. $102-24$.

32 The report on the latest excavations of the harbour in Pisa, Italy, speaks of the discovery of a whole human skeleton from the first century CE, with an adjoining dog skeleton. The excavators surmise that the man worked in the harbour and the dog was his pet. The dog skeleton is similar to that of a basset hound, that is known both as a hunting dog and as a pet, and that was popular in harbours and in ships, for its ability to hunt mice and other rodents. These excavations also yielded the remains of an additional 16 dogs that probably filled similar roles. See Greg Burke, 'Anchored in History', Time (March 13, 2000), p. 56

33 J. P. V. D. Balsdon, Life and Leisure in Ancient Rome (London, 1969), p. 91; G. van Hoorn, Choes and Anthesteria (Leiden, 1951), p. 45.

34 E. Eyben, Restless Youth in Ancient Rome (London and New York, 1993), pp. 102-03. 
memory. ${ }^{35}$ Like the Greeks, the Romans sometimes offered up dogs as sacrifice. ${ }^{36}$

Dogs were also often connected to the realm of games and gambling. Thus, the pieces in board games were occasionally called 'dogs', and the dice player lost if he threw 'canes [dogs]', the lowest number obtainable by the casting of four dice, with the number one showing on each die. ${ }^{37}$ This appellation clearly indicates that despite the positive turnabout in the attitude to dogs in the Graeco-Roman world, some degree of ambivalence toward these animals still remained.

Although, for the Romans, the dog could be a faithful companion, possessing medicinal and ritual attributes, they never forgot that a dog, after all, was a dog, explaining the occasional depictions of dogs as impure, as carrion eaters, or simply as violent animals capable of biting, or worse. ${ }^{38}$ The attitude toward the dog in the Roman world was apparently determined on the basis of this animal's standing: a positive approach to the pet and the domesticated animal, and a more negative one to the wild dog. Thus, the Romans were not totally and absolutely canine-friendly in all circumstances, in contrast with, for example, the situation in Egypt (above), or that in Persia (below). The Graeco-Roman world also was familiar with negative canine images, and mentioned them together with positive motifs. ${ }^{39}$

\section{The East: Persia}

The Persians did not merely like their dogs, they venerated them, an attitude that was probably based on the important service provided by sheep dogs and guard dogs in ancient nomadic Persian society, and was also connected to canine-related theological notions of Zoroastrianism. ${ }^{40}$ Accordingly, the dog was afforded a place immediately following that of man in the hierarchy

35 G. Jennison, Animals for Show and Pleasure in Ancient Rome (Manchester, 1937), p. 127. See also Brewer, Clark and Phillips, Dogs in Antiquity, p. 93.

36 Dog sacrifices were offered, e.g., to the Lares Praestites that guarded the borders. See Bell, Dictionary of Classical Mythology, p. 68. Likewise, red puppies were sacrificed, and their entrails were examined in the augurium canarium ceremony; a red dog was sacrificed at the Robigalia, in order to prevent harm to the harvest or avert damage from the heat of Sirius, the Dog Star. For all these rituals, see Burris, 'The Place of the Dog', pp. 32-35.

${ }^{37}$ See Balsdon, Life and Leisure, p. 151; see also J. Schwartz, 'Gambling in Ancient Jewish Society and in the Graeco-Roman World', in M. Goodman (ed.), Jews in a Graeco-Roman World (Oxford, 1998), pp. 145-65.

38 See Wapnish and Hesse, 'Pampered Pooches', p. 72; see also L. P. Day, 'Burials in the Greek World', American Journal of Archaeology 88 (1984), p. 29 n. 38. At times, however, even violent acts were beneficial. See e.g. Burris, 'The Place of the Dog', for a wild dog carrying a man's hand in its mouth that passed by the emperor Vespasian, thereby auguring that the emperor would attain whatever he desired. Cf. V. Olivova, Sports and Games in the Ancient World, trans. D. Orpington (New York, 1985), pp. 158-59, for the sixth century BCE Etruscan tomb known as the 'Tomb of the Augurs', that bears a depiction of a dog attacking a man who attempts to repel it.

39 See Brewer, Clark and Phillips, Dogs in Antiquity, pp. 100-01. Cf. the sources in J. G. Mueller, Des Flavius Josephus Schrift Gegen den Apion, Text und Erklaerung aus dem Nachlass (Basel, 1877 [Hildesheim, 1969]), p. 262.

40 See M. Boyce, A History of Zoroastrianism, I: The Early Period (Leiden, 1989²). 
of creation. ${ }^{41}$ The dog was said to represent the world of the dead, and an offering was made to the dead by physically feeding it to a dog. The dog could also offer protection against the world of the dead, and demons and evil spirits would flee from its gaze; it was likewise the faithful escort of the soul of the deceased on its journey to the netherworld. The bodies of the dead in Persia were not buried, but rather remained in towers to which dogs (and birds of prey) had access. ${ }^{42}$ In contrast with the practice in the Graeco-Roman world, in which dogs were fed bits of food and leftovers from the meal, pious Zoroastrians would offer food to their dogs before beginning their own meal, and even the less religiously inclined scrupulously observed this custom on holidays. ${ }^{43}$

Zoroastrianism also boasted an extensive canine literature, most of which has been lost. ${ }^{44}$ Thus, for example, chapters (fargard) 13 and 14 of the Vendidad (or Videvat), that are concerned with the ritual purity laws, contain an extensive discussion of the dog and like animals. Mention is made of the different types of canines in the Persian world, such as sheep dogs, herding dogs, guard dogs, and house dogs; the tasks allotted to each breed of dog; the punishments imposed on the person who harmed dogs in any manner, such as the giving of spoiled food; and the punishments imposed on a dog that bites. These chapters also contain a paean to the dog in which it is compared to a priest, a hero, the householder, a poet, a child, and more. ${ }^{45}$ The Persians especially emphasised the importance of their sheep dogs and hunting dogs, while not forgetting the house dog who guarded against thieves and wolves, and was possibly a pet, as well. ${ }^{46}$ The Persians, however, did not always adhere to a strict zoological definition regarding 'dogs', but the animals that they brought into their homes, such as the hedgehog that rid the house of rodents and snakes, merely enhanced the standing of the canine in this world. ${ }^{47}$

\section{Jewish Society}

It comes as no surprise that most of the Jewish sources from the Second Temple period and the time of the Mishnah and Talmud continue to maintain the negative attitude toward dogs expressed in the Biblical tradition. However, in a goodly number of instances, they do nonetheless acknowledge the usefulness of these creatures. We shall now examine the common motifs pertaining to canines in Jewish society of these times. ${ }^{48}$

41 Wapnish and Hesse, 'Pampered Pooches', p. 71; Boyce, op cit., pp. 302-03.

42 Boyce, op cit., pp. 120, 302-03.

43 Boyce, op cit., p. 163.

44 See J. Darmesteter (trans.), The Zend-Avesta, part I: The Vendidad (Oxford, 1895), p. 155.

45 Idem, pp. 154-85. Even the Persians, however, acknowledged the dog's limitations, and also compared it to a thief and a harlot.

46 Idem, p. 160.

47 Idem, p. 156 n. 1.

48 See also the general discussions by: L. Lewysohn, Die Zoologie des Talmuds (Frankfurt a. M., 1858), pp. 82-89; S. Krauss, Talmudische Archaeologie (Leipzig, 1911 [Hildesheim, 1966]), pp. 120-22, 510-11. The small dogs (guriyata) mentioned in BT Ketubot $61 \mathrm{~b}$ are not pets, as Lewysohn argued, but rather game pieces in board games. See Schwartz, 'Gambling in Ancient 


\section{Sheepdogs}

We shall begin our investigation with the sheepdog. Josephus mentions two types of dogs in his discussion of the Biblical prohibition against bringing 'the pay of a dog' into the house of the Lord (Deut. 23:19), as he rejects 'payment for the mating of a dog, whether hound of the chase or guardian of the flocks' and invalidates the use of such monies for offerings. ${ }^{49}$ Josephus does not mention a comprehensive ban against the breeding and the raising of dogs, especially regarding hunting dogs and sheepdogs; all that is forbidden is the bringing of a sacrifice purchased from the money received for their breeding. ${ }^{50}$ We shall first examine the 'guardian of the flocks', and then the hunting dog. ${ }^{51}$

No form of grazing was possible without herding dogs or sheepdogs, ${ }^{52}$ working dogs that were known for their loyalty to their masters; they efficiently and aggressively guarded the flock or herd against robbers and predators, and aided the herder in his work. ${ }^{53}$ Although most of the Jewish sources relating to sheepdogs are to be found in the Rabbinic literature, and not in that of the Second Temple period, there probably were no far-reaching changes in the work of these dogs, and we may assume that the depiction of the reality in Rabbinic sources is also valid for the Second Temple period. Thus, for example, we find in Gen. Rabbah 73:11 (ed. Theodor-Albeck, pp. 855-56):

R. Abba bar Kahana said: The Patriarch Jacob possessed 102 myriads, seven thousand, and one hundred $[=1,027,100]$ flocks of sheep. R. Levi said, Sixty myriads of dogs; and the Rabbis maintained: One hundred and twenty myriads $[=1,200,000]$ of dogs. They do not disagree; the one who said sixty myriads [maintained] that each flock had a single dog, while the one who said one hundred and twenty myriads [maintained] that each flock had two dogs. ${ }^{54}$

Jewish Society'; see also V. A. Keats, Chess in Jewish History and Hebrew Literature (Jerusalem, 1995), pp. 21-22.

49 Ant. 4.206 (trans. H. St. J. Thackeray, $L C L$, p. 575).

${ }^{50}$ For another interpretation of the verse, see: M Temurah 6:3 and parallels.

51 For such dogs in the Biblical period, cf.: Job 30:1 ('my sheep dogs'); Isa. 56:9-12.

52 See Schwartz, 'Dogs, "Water" and Wall'; cf. R. Coppinger and R. Schneider, 'Evolution of Working Dogs', in Serpell, The Domestic Dog, pp. 27-29 (sheep dogs), 29-31 (herding dogs). Jewish sources mention three types of grazing in antiquity: (1) in the desert, the year round; (2) in the desert, during the summertime; (3) in proximity to a settlement. In all of these types of grazing, sheep and herding dogs were very necessary. The professional shepherd who tended the flocks of the farmers in the area also needed dogs, and the owner of a private farm, with only a few sheep or goats, probably also was dependent upon sheep or guard dogs. See Z. Safrai: The Economy of Roman Palestine (London and New York, 1994), pp. 165-67.

53 Cf. the general treatment in Toynbee, Animals in Roman Life, pp. 106-07. An extremely detailed portrayal of sheepdogs and herding dogs appears in De re rustica by the first-century CE Roman author Lucius Junius Moderatus Columella; see 7:12:1-14. The Persian tradition asserts that sheep and cattle are dependent for their very existence upon sheepdogs and herding dogs. See Darmesteter, Zend-Avesta, Saddar 31, p. 168 n. 1. It often happens in the modern period that sheepdogs and herding dogs have no work, resulting in problems of 'unemployment'. Some have undergone vocational retraining to occupations no less important. Thus, the Border Collie drives off birds from airports, fish ponds, and the like; see the report by Tzafrir Rinat, 'The Dog as Obsessive Workaholic', Haaretz (February 23, 2000), p. B6 (in Hebrew).

54 Cf. the parallel in Tanhuma, Vayetze 24 (ed. Buber, fol. 81a), with minor changes. 
All of the figures in this tradition regarding the number of flocks that Jacob presumably possessed upon his return to the Land of Israel from the house of Laban are obviously imaginary. The intent of the tradition is to stress that Jacob possessed many flocks, and consequently, a great number of sheepdogs, as well. Of greater interest are the different approaches concerning the number of sheepdogs required for a flock, that is, is one dog necessary, or two. Both approaches apparently reflect the same reality: small flocks of between two and five sheep required only a single dog, whose sole responsibility was to guard the animals. In larger flocks, the dog was expected not only to guard the flock, but also to lead it, together with the shepherd, thus requiring two dogs, one behind the flock, and the other in front. This midrashic tradition portrays numerous (and probably large) flocks, that had to travel large distances; in such an instance, two sheepdogs were needed for each flock.

Other sources as well are cognizant of the need for two sheepdogs per flock, as in Sifrei, Num. 157 (ed. Horovitz, p. 209):

To what is this comparable? To two dogs that were with a flock and were angry with one another. A wolf came to take a lamb from the flock, and one of [the dogs] began fighting it. Its fellow said, If I will not come to its aid now, it will kill it, then come behind me and kill me. They made peace with each other, and fought the wolf. ${ }^{55}$

The tradition is silent concerning the size of the flock, but makes explicit mention of two dogs. Although they could be expected to work in harmony, and despite the high level of sheepdogs, it must be remembered that they are still dogs, and at times would not get along. ${ }^{56}$ In the case depicted by Sifrei, despite the seeming 'personality clash' between the two dogs, at the decisive moment they act just as is required of sheepdogs, protecting the flock and even warding off the attack by the wolf..$^{57}$

Wolves were not the only enemies faced by these dogs. Ben Sira cites a maxim concerning a hyena that attacks a $\operatorname{dog} .{ }^{58}$ sheepdogs were also subject to assaults by wild dogs, ${ }^{59}$ and could even incur injury from the animals that they guarded, especially if these were large beasts. ${ }^{60}$ All these provided additional reasons for two dogs per flock, and not a single one.

In order to function properly, sheepdogs required a richer diet than that consumed by most dogs. ${ }^{61}$ We read in M Hallah 1:8 of 'dog's-dough', from

55 Cf. the parallels in BT Sanhedrin 105a; Tanhuma, Balak 4 (ed. Buber, fol. 67b); Tanhuma, Balak 3; Num. Rabbah 20:2.

56 See BT Bekhorot 55a. Some sheepdogs did not obey their masters. For sheepdogs banding together against a common enemy, such as a wolf, see S. Thompson, Motif-Index of FolkLiterature (Copenhagen, 1958), vol. 6, p. 223 (J624.2). In time of trouble, dogs, and especially hounds and sheepdogs, tend to band together (allelomimetic behaviour) (see J. L. CloudsleyThompson, Animal Behaviour [New York, 1961], p. 152). This helps us to understand the behaviour of the two dogs against the common enemy in this tradition.

57 For the aggressive behaviour demanded of these dogs, see Columella, De re rustica 7:12:9.

58 Sirach 13:20 (ed. Segal, p. 82).

59 M Bava Metzia 7:9.

${ }^{60}$ PT Bava Kamma 2:6 (3[a]).

61 The halachah, obviously, established the owner's obligation to feed his dog. See e.g. BT Shabbat 155b; cf. T Yom Tov 2:6 (ed. Lieberman, p. 287). Sheepdogs, like other breeds, 
which the herdsmen would also eat, and that therefore was subject to all the halachic requirements of dough that was intended for human consumption. ${ }^{62}$ According to R. Simeon ben Lakish, this was a dough supplemented by bran, ${ }^{63}$ probably to aid the dogs' digestive system. The Roman tradition specifically prescribes giving these dogs good food: oat flour and milk, or bread with lentil water, foods that were meant to strengthen the dog and aid its digestive system. ${ }^{64}$ The fact that this dough was also baked in shapes similar to loaves of bread or cakes likewise attests to the enriched nature of this bread that was earmarked, from the outset, for dogs. ${ }^{65}$

These dogs often earned this special food and treatment because they guarded their masters, as well as the flock. Thus, for example, PT Terumot 8:7 (46[a]):

Shepherds milked [their animals], and a serpent came and ate of [the milk, and left poison in it]. The dog looked at it when the shepherds came and wanted to drink the milk. The dog barked at them, but they paid no heed, until, finally, it consumed it [the poisoned milk] and died.

The parallel to this narrative, in Pesikta de-Rav Kahana, Vayehi Beshalah 1 (ed. Mandelbaum, pp. 175-76), adds:

And they buried it, and erected a monument for it, that is now called 'the dog's tombstone. ${ }^{66}$

Since sheepdogs were known for their loyalty to the flock and to their master, any exception to this rule would arouse surprise, ${ }^{67}$ which apparently was the aim of the author of Enoch in his portrayal of human and Israelite history (89:42-49), as he employs the imagery of beasts and other animals, adding dogs to the foxes and wild boars that attack the flock, instead of defending it. ${ }^{68}$ The sheep are identified with Israel, the dogs with the Philistines, the

could naturally be satisfied with the eating of carrion (BT Betzah 21a) or a bone (Ant. 12.288 ff.; BT Shabbat 128a). Additionally, meat was sometimes slaughtered for consumption by dogs ( T Hullin 2:15 [ed. Zuckermandel, p. 502] — we are not referring, here, to the slaughtering performed in the Temple Court).

62 See the sugyah in PT Hallah 1:9 (58[a]). At times, however, this might attest to the meagre food of the herders themselves. Some herders refrained from eating this dough. Cf. BT Eruvin 81a, for the casting of lentil bread to the dogs (in Babylonia), and their refusal to eat it. See also below, the discussion on the feeding of dogs.

63 Ibid.

${ }^{64}$ Columella, De re rustica 7:12:10. Cf. Brewer, Clark and Phillips, Dogs in Antiquity, p. 72. Certain dogs, such as sheepdogs, received choice food in the Ancient Near East, as well.

65 T. Hallah 1:7 (ed. Lieberman, p. 276) and PT Hallah ad loc. If they were baked in the form of a mould that is not the usual shape of a loaf, then the shepherd was not required to relate to this as human food.

${ }^{66}$ S. Lieberman, Greek in Jewish Palestine (New York, 1965), p. 126 n. 91, argues that this and similar narratives in the Rabbinical sources reflect positive motifs concerning dogs that were common in the Graeco-Roman world. Even if Lieberman is correct, the fact that this motif entered the literature of the Rabbis probably indicates that they, too, thought that a faithful sheepdog would act in such a manner.

67 As was noted above, however, this is, after all, a dog. So, too, in PT Sanhedrin 2:3 (20[b]): " "One who urinates against a wall" [I Sam. 25:22, 34] — why are we occupied with a dog, that urinates against a wall.' See also BT Bava Batra 19b.

${ }^{68}$ Cf. BT Bava Kamma 15b. It should be noted that the dogs in Babylonia usually did not eat sheep, and the Land of Israel dogs were most likely no different in this respect. 
foxes with Ammon or Amalek, and the wild boars with Edom. ${ }^{69}$ The use of the dog to symbolise the Philistines is particularly intriguing, in light of the large Persian period dog cemetery that was unearthed in Ashkelon, a city that is identified in the Biblical period with the Philistines. ${ }^{70}$

All the above relates to sheepdogs and herding dogs in the service of professional herders who roamed with their flocks or herds far from settled area. Smaller herds that went out to graze close to the settlement would be brought back to sheep folds or pens within the settlement itself. ${ }^{71}$ Sheepdogs were undoubtedly needed in the latter category, as well, to guard the sheep against harm, whether in their pen or outside it, work that was undoubtedly more difficult for the dogs than their labours on the open range. ${ }^{72}$

\section{Hunting Dogs}

We saw above that Josephus mentions hunting dogs. ${ }^{73}$ These dogs were popular among many peoples in the ancient world, especially among those for whom hunting was a major occupation. ${ }^{74}$ Among Jews, however, in contrast with the many sources mentioned above regarding sheepdogs and herding dogs (that apparently reflect the great Jewish interest in these realms), only a single source, in addition to what Josephus mentions, possibly alludes to such hounds, a datum that may, in turn, indicate the scanty Jewish concern with hunting. ${ }^{75}$ Thus, chapter 2 of the Testament of Judah speaks of Judah's hunting skills. He catches and kills a deer, a gazelle, a lion (in the process rescuing a kid from its mouth), a bear, and a wild boar. This source also relates (2:6) that a leopard attacked a dog in Hebron, and Judah seized the tail of the leopard and killed it. It is uncertain whether the Testament actually depicts Judah as a hunter or simply as one who killed wild animals that chanced to cross his path, and who happens to be accompanied by a dog. We therefore have difficulty in understanding Josephus' intent when he portrayed the Jews

69 M. Black, The Book of Enoch or I Enoch: A New English Edition (Leiden, 1985), p. 267.

70 See e.g.: Josh. 13:3; Jud. 14:19; II Sam. 1:20. For this cemetery and the finds it contained, see the discussion above; L. E. Stager, 'When Canaanites and Philistines Ruled Ashkelon', Biblical Archaeology Review 17.2 (1991), pp. 24 43; idem, 'Why Were Hundreds of Dogs'; Wapnish and Hesse, 'Pampered Pooches'.

71 See e.g. M Bava Kamma 6:1; cf. Safrai, Economy.

72 See: M Bava Kamma 2:3; T Bava Kamma 2:1 (ed. Lieberman, p. 5); PT Bava Kamma 2:5 (3[a]); BT Bava Kamma 21b. The reference is to dogs and lambs that jump and/or fall (or skip) down from roofs, or jump up, and thereby cause damage. The dogs that were together with the lambs were probably sheepdogs (or guard dogs). The sources do not indicate that these lambs and goats spent the entire day in their pens, thus adding to the responsibilities of the dogs. See below, the discussion on guard dogs.

73 Ant. 4.206.

${ }^{74}$ See Mery, Life, History, and Magic, pp. 31, 34-35, 40, 46-47, and more.

75 See Lewysohn, Zoologie, p. 89. There is no mention in all of Rabbinic literature of a dog of this type. See Rashi on BT Bava Kamma 80a, s.v. 'Kufrin', who understands these to be 'large dogs of hunters', but kufrin is not to be interpreted in this manner. See Lewysohn, loc. cit.; and our discussion, below. For Jews and hunting, see M. Mainzer, 'Jagd, Fischfang und Bienenzucht bei den Juden in der tannaeischen Zeit', MGWJ 53 (1909), pp. 174-89, 303-27, 453-68, 539-62. Cf. J. Schwartz, 'Pigeon Flyers in Ancient Jewish Society', Journal of Jewish Studies 48 (1997), pp. $105-19$. 
as raising hunting dogs; the Jews may possibly have raised such animals for use by Gentiles who engaged in hunting. ${ }^{76}$

\section{Watchdogs}

One of the dog's most important tasks was guarding its owner's house, courtyard, and property. ${ }^{77}$ Columella describes the perfect dog for such tasks: he must be big, with a strong voice, whose appearance and barking will deter all manner of wild beasts or thieves. ${ }^{78}$ In contrast with sheepdogs, whose owners preferred them to be white-haired, to distinguish them from wild animals, black hair was a requirement for the guard dog, in order to scare intruders and as nocturnal camouflage. ${ }^{79}$ The watchdog had to be sufficiently patient to perform its guard duties, and had to refrain from inordinate wandering outside the house and courtyard area. He was required to be lively, but not excessively so, since he usually did not guard a large area. He had to be aggressive, to protect himself and 'his space', but not overly so, in order not to attack the members of the household. ${ }^{80}$

The fundamental contribution of the dog to security is well-known. A tradition in the Babylonian Talmud, for example, states that a person should not live in a place 'where no horses neigh or dogs bark' ${ }^{81}$ It could, however, be argued that this maxim speaks of dogs in general, and does not necessarily re-

76 Cf. e.g. M Avodah Zarah 1:7. It is doubtful whether the hunting scenes in the mosaic pavements in the Land of Israel, that include hounds, contribute much to the history of hunting among either Gentiles or Jews in the Land of Israel. More plausibly, these scenes reflect widespread artistic motifs. Hounds in pursuit of different animals, for example, appear in the mosaic pavement of a Roman villa (that became a Christian chapel) in Beth Gubrin (M. AviYonah, Art in Ancient Palestine: Selected Studies [Jerusalem, 1981], p. 293); in a room on Mount Zion belonging to the Franciscans (idem, p. 317); in a mosaic pavement in the church in Kissufim (R. Hachlili, Ancient Jewish Art and Archaeology in the Land of Israel [Leiden, 1988], p. 339); in a third- or early fourth-century mosaic pavement in Lod (M. Avisar, 'Lod-Mosaic Pavement', Qadmoniot 32 [1999], pp. 41-43, in Hebrew). An additional excavation area, to the south of this mosaic, yielded an additional, earlier, mosaic pavement that also contains depictions of animals and hunting scenes; this mosaic has not, however, been examined, and has been covered; and in a mosaic pavement in Shechem (C. Dauphin, 'A Roman Mosaic Pavement from Nablus', IEJ 29 [1979], pp. 11-33). The dogs in Lod and in Shechem are portrayed with an identical harness. A number of hounds also appear in Jewish remains, but, as was noted above, it is questionable whether they teach a great deal about any Jewish connection to this activity. In addition to all these, Erwin Goodenough mentioned a Jewish oil-lamp with a depiction of a hunting dog chasing a rabbit. Goodenough claimed that the lamp that he found in a shop in Beirut, had a menorah engraved on it, thus establishing its Jewish nature (E. R. Goodenough, Jewish Symbols in the Graeco-Roman Period [New York, 1953], vol. 1, p. 142). The mosaic pavements of synagogues in Beth Shean and in Gaza contain scenes of a hound chasing a deer (Hachlili, op cit., p. 339).

77 See Columella 7:12:2-3.

78 Cf. Coppinger and Schneider, 'Evolution of Working Dogs', p. 27.

79 Cf. Brewer, Clark and Phillips, Dogs in Antiquity, p. 71. Interestingly, in the Sumerian literature, the sheepdog (ur-nam-sipa-da) is black, and not white.

80 Columella 7:12:3-7.

81 BT Pesahim 113a. The sounds made by dogs or their behaviour sometimes indicated other matters. Thus in BT Bava Kamma 60b: 'Our masters taught, if dogs howl, the Angel of Death has come to the city; if dogs frolic, the prophet Elijah has come to the city. This is so, however, only if there is no female among them.' A sad dog augurs death, while happy canines foretell the advent of the Messiah. All this is true, of course, if there is no female dog in the vicinity to arouse them, thereby influencing their behaviour. Cf. also Burris, 'The Place of the Dog', p. 35. 
fer to guard dogs, ${ }^{82}$ either public or private, or that these were wild dogs that roamed through the streets of the settlement at night. ${ }^{83}$ It is difficult, however, to comprehend why the inhabitants of any locality would pay heed to just any barking that they probably heard the entire night; it is hardly conceivable that any ordinary dog, or a wild one, would be capable of distinguishing between a stranger or a potential danger, on the one hand, and the local residents, on the other, and the barking of a wild dog that roams about and makes noise at any disturbance is of dubious utility. The tradition more plausibly refers to some sort of watchdogs, although it is difficult to determine whether the Babylonian tradition refers to dogs that acted on behalf of the community as a whole, or to watchdogs and yard dogs whose protection of their owner's property also provided a measure of defence for the settlement in its entirety. ${ }^{84}$ Some Rabbis also demanded that guard dogs, especially those 'in towns near the border', be restrained with iron chains during the day, and let free only at night, the critical time for settlement defence. ${ }^{85}$

Most of these dogs, as was noted, were responsible for guarding the courtyard and the property it contained. It was expected that if a stranger were to enter the courtyard without permission, these animals would act as 'dogs', that is, that they would make a great commotion. The Mishnah therefore establishes (Bava Kamma 5:3) that if someone brought an ox into the courtyard of the householder without permission, 'and the householder's ox gored it or the householder's dog bit it', the householder is exempt from paying damages to the owner of the ox, since the dog was fulfilling the task imposed on it. ${ }^{86}$ The Mishnah adds that if the owner of the courtyard gave his permission to bring in the ox, then the householder is liable for the damage done by his ox or dog. Interestingly, R. Judah exempts the householder, even if he gave someone permission to enter, unless he explicitly stated that he assumed responsibility for the beast that was brought in. According to R. Judah, a guard dog cannot be expected to automatically cease to act in this capacity, even if permission to enter the courtyard had been given.

82 Even a dog that does not bark can be noisy. See e.g. Pesikta de-Rav Kahana, Vayehi Beshalah 12 (ed. Mandelbaum, pp. 187-88): 'R. Yuden said: Because this dog snarls with its tongue.' Other dogs, in contrast, do not bark at all. A Babylonian tradition asserts that a dog in strange or new surroundings does not bark for seven years: 'A dog that is not in its place will not bark for seven years' (BT Eruvin 61a). Cf. Lewysohn, Zoologie, p. 86.

${ }^{83}$ See e.g. BT Berakhot 3a. In the second nocturnal watch 'dogs bark'. For the most part, however, only domesticated dogs bark or make other noises, while wild dogs usually maintain relative silence. See Clutton-Brock, Domesticated Animals, p. 39.

${ }^{84}$ See Z. Safrai, The Jewish Community in the Talmudic Period (Jerusalem, 1995), pp. 98-122 (in Hebrew). Rabbinic sources concerning security matters usually relate to human guards, or physical elements such as walls or towers.

85 T Bava Kamma 8:17 (ed. Lieberman, p. 41). See also BT Bava Kamma 83a: 'He should keep it chained during the daytime and release it only at night.' See the discussion below regarding canine violence.

${ }^{86}$ Cf. T Bava Kamma 5:13 (ed. Lieberman, p. 20), that prescribes: 'It is stoned, and no indemnity can be paid [instead].' The question of indemnity (Ex. 21:29-30) probably refers solely to an ox, and not to a dog, since the rest of the chapter in the Tosefta is concerned with the damage caused by oxen or cows. It is highly unlikely that the dog was capable of killing the ox; at any rate, the dog is not included among the animals that habitually cause damage, such as the lion, the bear, the serpent, and the like (M Bava Kamma 1:4; PT Bava Kamma 1:5 [2(c)]). 
An additional law in the Tosefta (Bava Kamma 6:27; ed. Lieberman, p. 27) establishes:

If a worker entered the courtyard of the householder without permission, even though he is entitled to enter and collect his wages, and the ox of the householder gored him, or the dog of the householder bit him, he [the householder] is exempt [from the payment of damages to the worker]. If he told him: 'Enter', the householder is liable [damages].

It is unclear why the householder is exempt from paying the workman who came to collect his wages. The Talmud explains (BT Bava Kamma 33a) that this refers to a case in which the nature of the permission granted by the householder to the workman to enter and receive his wages is vague; perhaps the householder's intent was that the workman only come as far as the entrance to the courtyard, where he would be met by the householder with his pay. In any event, the courtyard dog patently acted as it was required in such circumstances, and no claims were raised against the householder because of the dog's aggressive behaviour.

Despite the above, the householder was obliged to take care regarding the watchdog, and was liable for the damages caused by the dog that are unrelated to its function. Thus, for example, M Bava Kamma 7:7 states that dogs may not be raised at all unless they are chained ${ }^{87}$ Obviously, the taking of precautionary measures was not exceptional, and such steps were taken by other peoples as well. ${ }^{88} \mathrm{M}$ Bava Kamma 2:3 establishes that if a dog ate a hararah (a thin cake baked on coals in the courtyard) that did not belong to its owner, the householder is liable to pay full damages, since a dog habitually engages in such conduct, and its owner should have supervised the animal. If the cake was still so hot that live sparks were still on it, and the dog burnt the stack of grain with it, the householder is liable only half damages, since such an instance is possibly less foreseeable.

Our discussion until now was concerned with dogs whose primary task was to guard the courtyard, and whose owners probably belonged to the middle or lower classes of society. The wealthy and esteemed also possessed watchdogs, whose guard duties were more important than those discussed above, as befitting the more exalted standing of their owners. Most of the sources of this type presumably refer to kings, but clearly are concerned with the upper socioeconomic class in general. Thus, for example, we find in Pesikta de-Rav Kahana, Zekhor 9 (ed. Mandelbaum, p. 47):

The king had a vineyard that was surrounded by a fence, and the king placed in it a dog that was accustomed to bite. The king said, Whoever comes and breaches the fence will be bitten by the dog. The king's son came and breached the fence, and the dog bit him. ${ }^{89}$

\footnotetext{
${ }^{87}$ See the discussion, below, regarding canine violence. This tradition reflects the ambivalent attitude toward dogs, even those that fulfill important functions.

${ }^{88}$ See e.g. Darmesteter, Zend-Avesta, p. 164, regarding the taking of precautionary measures regarding house and courtyard dogs in the Persian world.

89 See the parallels: Tanhuma, ed. Buber, Tetze 12 (fol. 21a); Pesikta Rabbati, Zekhor 12 (fol. 52a) (pardes [garden] instead of kerem [vineyard]); Pirkei de-Rabbi Eliezer 44 pardes.
} 
As was mentioned, a watchdog had to be aggressive. In this case, the king selected a particularly vicious dog 'that was accustomed to bite', and that even attacked the king's son, who entered the vineyard without permission. We shall see below that the difference between an effective guard dog and a vicious one is at times quite small. A guard dog as described here, even the most effective, is not appropriate for the house or courtyard, but apparently was suited for the role of vineyard guard.

Although this tradition provides a relatively large amount of information regarding the nature of the $\mathrm{dog}$, it leaves other issues unanswered. Thus, it has not been determined whether the presence of guard dogs in vineyards (or, according to some of the sources, in orchards) was common among society as a whole, or only among the upper classes. We are similarly unclear regarding the degree to which these two elements of guarding were related: was the fence necessary for the dog to perform its guard duties, or was it only an addition erected by the wealthy individual for the protection of his property, while the dog was capable of guarding even an unfenced vineyard? ${ }^{90}$

The wealthy patently used watchdogs within their houses, as well; at times these animals were violent or potentially so. Thus Eccl. Rabbah (5:10) relates that King David would spend the Sabbath in the orchard behind his house, where he died. When his son Solomon discovered this, he informed the sages in the study hall that 'Father died and is lying in the heat, and the dogs of father's house are hungry.' ${ }^{91}$ This midrash most likely does not refer to pets, who would have recognised David and were accustomed to accompany him, but to the king's guard dogs, who had no qualms about eating from his corpse if they were sufficiently hungry. Solomon wished to be rid of the dogs, so that he could remove his father's body from the garden in the halachic manner suitable for the Sabbath. The sages sent back the following message: 'Cut up a carcass and set it before the dogs; [as for] your father, place a loaf or an infant on him, and carry him ...' The proposed solution, as well, is not indicative of pets, but of guard dogs, who regularly eat meat. At any rate, it is not inconceivable that wealthy Jews kept the latter in their homes to guard themselves and their possessions.

There is also an additional type of watchdog. The late aggadic literature that is concerned with the Exodus depicts magical guard dogs in the service of the Egyptians that would bark if anyone approached them. ${ }^{92}$ These creatures

90 The fence enclosing the vineyard was built to protect against the various types of pests. A fence obviously is not effective against birds, but it can hinder infiltration by foxes, wild boars, and other wild beasts; by shepherds who would lead in their flocks, that would destroy the vines by eating the grape leaves; by thieves who picked the grapes, thus stealing the crop for themselves; or by the ordinary passersby, who would not refrain from eating grapes that did not belong to him. See: Y. Feliks, Fruit Trees in the Bible and Talmudic Literature (Jerusalem, 1994), p. 80 (in Hebrew). A vicious dog obviously enhanced the physical system protecting the vineyard. For field towers, see Safrai, Jewish Community, p. 103 n. 183 and the literature cited there. The towers primarily filled an agricultural function, but at times also added an element of security.

91 Cf. Lev. Rabbah 19:26 (pp. 433-34), according to which Nebuchadnezzar "would cut pieces of [Jehoiakim's] flesh, and throw it to the dogs, as it is said: "He shall have the burial of an ass" [Jer. 22:19] — where is the burial of an ass, if not in the belly of a dog?

92 See Burris, 'The Place of the Dog', p. 34. Roman temples employed guard dogs, whose 
were liable to warn of the flight of the Israelites and alert the Egyptians. Thus we find in Ex. Rabbah 20:19:

The Egyptians employed sorcery to make golden dogs, who would bark if anyone were to come there, and their voice would be heard throughout Egypt, a forty days' walk across. Moses silenced them, as it is said, 'But not a dog shall snarl at the Israelites' [Ex. 11:7].

In this midrash, the dogs began to bark and Moses silenced them; the verse does not refer to the dogs that accompanied the Israelites, but rather to the magical watchdogs. The tradition appears in slightly altered form in Pesikta de-Rav Kahana, Vayehi Beshalah 11:12 (pp. 187-88):

There were two dogs [produced] by sorcery there, and they began barking at Moses. Moses said: People, come and see: dogs of truth do not bark, while dogs of falsehood do bark.

It is not related expressly here that Moses silenced them, but the midrash can reasonably be understood in this manner. The intent of the verse from Exodus is to the dogs of the Israelites, that made no noise during the Exodus. In reward for their so uncharacteristic silence, another late tradition maintains that the hides used for Torah scrolls, tefilin, and mezuzot would be tanned with their excrement. ${ }^{93}$

\section{Companions and Pets}

The earliest Jewish source to relate to the dog as a companion or almost as a pet is the Book of Tobit. In this story, Tobias is sent by his father Tobit to the land of Media, and his dog goes with him, and also accompanies him on his way home. ${ }^{94}$ Scholars experienced difficulty in explaining the role of the dog in the narrative. According to one scholarly view, in the early versions of the book the dog's task was to guard Tobias against the great fish or crocodile that is depicted in the story, with this guard function being lost over the course of time. Other authorities took note of traditions in the Greek and Persian worlds that portray the dog as a faithful companion, such as the dog of Odysseus (see above), but immediately added a reservation to this in-

barking was meant to warn of the approach of an enemy or intruder to the temple.

93 Kallah Rabbati 7:1. For the use of dog dung in the tanning of hides, see also: T Berakhot 2:16 (ed. Lieberman, p. 9); PT Berakhot 3:5 (6[d]); BT Berakhot 25a. See also: BT Gittin 69a, for the medicinal uses of the dung of a white dog (Album Graecum); cf. the sugyah in Gittin for additional folk remedies involving dogs and other animals. For this entire subject, see: F. Rosner (trans. and ed.), Julius Preuss' Biblical and Talmudic Medicine (New York,1983), p. 269. See also M Ketubot 7:10: 'These are the ones who are compelled to divorce [their wives]: the one who is afflicted with boils, the one who has a polypus, the collector, the coppersmith, or the tanner [...].' The 'collector' gathers dog manure for the tanning of hides; according to this mishnah, this is an extremely despised occupation. Cf. T Ketubot 7:11 (ed. Lieberman, p. 82): 'Who is the collector? This is the tanner; according to another opinion, this is the collector of excrement.' For additional sources on this subject, see S. Lieberman, Tosefta ki-Fshutah, 6, Order Nashim (New York, 1967), pp. 302-04. Cf. also Burris, 'The Place of the Dog', pp. 32-35; Brewer, Clark and Phillips, Dogs in Antiquity, p. 42.

94 6:2;11:4 (5:16 and 11:9 in other versions; see C. A. Moore, The Anchor Bible: Tobit: A New Translation with Introduction and Commentary [New York, 1996], p. 197). 
terpretation, in light of the negative motifs concerning dogs in the Biblical tradition. ${ }^{95}$ It is plausible that both approaches are correct: the canine companion was also supposed to protect its master for some reason, ${ }^{96}$ whether from a large fish or from some other dangerous creature, in a story that may well have marked the turning point from the almost totally negative Biblical approach, to the more positive attitude of the Second Temple period. ${ }^{97}$

The motif of a dog companion who is also a personal guard appears in the Rabbinic sources. ${ }^{98}$ Thus, on the verse 'And the Lord put a mark on Cain, lest anyone who meet him should kill him' (Gen. 4:15), we find the exposition in Gen. Rabbah (22:12; ed. Theodor-Albeck, p. 219): 'Rav said: He gave him a dog', so that the dog would protect him against wild, dangerous animals and show him the right path. Nonetheless, something of the negative standing of the dog in Eastern tradition remains, and so specifically this animal was chosen to accompany the murderer, especially since a dog does not distinguish between a 'moral' master or an 'immoral' one, and generally is loyal to any master, without 'judging' his actions. ${ }^{99}$ This approach made possible the ironic approach in Pirkei de-Rabbi Eliezer 21 that 'the dog that guarded Abel's flock was his [Cain's] guardian against the wild beasts and the birds of the sky.'

We have already encountered (above) the motif of sheepdogs who also guarded their masters' lives, a theme that recurs in regard to house dogs. Thus, the continuation of the above tradition in PT Terumot 8:7 (46[a]), concerning the sheepdog that saved the shepherds from death, contains the following narrative:

A certain person invited a sage to his home, and [the householder] sat his dog next to him. [The sage] asked him, 'How did I merit this insult?' [The house-

95 For a summation of these views, see Moore, Tobit, pp. 197-99.

96 The intriguing report by Z.Rinat ('The Dog as Obsessive Workaholic') tells of different breeds of dogs that were developed for use as working dogs (such as the Border Collie) and that obsessively seek work, even if pets. The dog naturally incorporates many traits both on the job and when off duty.

97 The dog became a popular motif in many paintings that portray the journey of Tobias, but the role of the dog was downplayed in many presentations based on this narrative. The dog remained, however, in the 1930 play by James Bridie, Tobias and the Angel, while Franz Joseph Hayden (1732-1809) already excluded it from his oratorio Il ritorno di Tobia, and Arthur Bliss and Christopher Hassal similarly make no mention of the dog in their opera (1960), that also is called Tobias and the Angel. The new opera by Jonathan Dove, that repeats this name, Tobias and the Angel also omits any reference to the dog. For all these literary occurrences, see the article by A. Porter, 'Let No Dog Bark', Times Literary Supplement, 16 July 1999, p. 20.

98 There were other sources of concern in Babylonia. See BT Bava Metzia 71a (= BT Avodah Zarah 22b): 'For R. Joseph taught: A widow may not breed dogs.' But see the Tosafot ad loc.: 'because of slander going about, since it follows her, so that an Israelite would not be suspected of homosexuality or bestiality.'

99 We follow the interpretation by Nahmanides of this midrash: 'Since he feared the beasts, He gave him one of them to walk before him, and wherever the dog turned to go, Cain knew that God commanded him to go there and that he would not be killed by any living creature. Now the Sages singled out a contemptible sign [a dog] as was befitting him, but the intent is that there was with him a perpetual sign showing him the way to go for such is indicated in the word vayasem (and He appointed)' (Ramban [Nachmanides] on the Torah, trans. C. B. Chavel [New York, 1971], p. 92). Tanhuma, Bereshit 10, in contrast, makes no mention of the dog. 
holder] responded, 'My master, I am repaying him for his goodness. Kidnappers came to the town, one of them came and wanted to take my wife, and the dog ate his testicles.' 100

Notwithstanding this, canine loyalty was not always properly rewarded. Thus Josephus tells of the baaras (baaris=mandragoras) plant that grows in Transjordan, in a place also called Baaras. Everyone wanted it, but anyone who touched the plant before it had been picked faced certain death. Josephus describes the various stratagems employed to pick the plant: for example, people would dig around it, and then tie to the plant a dog, who unsuspectingly followed his master. The dog pulled out the plant and died. As Josephus puts this: 'a vicarious victim, as it were, for him who intended to remove the plant'. ${ }^{101}$

Obviously, not all dogs sat at the table, or were given the food served there, as we saw concerning the dog that had saved his master's wife. ${ }^{102}$ As was noted above, sheep dogs and herding dogs enjoyed a superior diet. Although it is doubtful whether every house dog or pet received such food, ${ }^{103}$ the owners of these animals naturally were obliged to feed them. Thus, in BT Shabbat 155b:

Food is put before the dog, but is not put before the pig. What is the difference between them? You are responsible for the food of one [the dog], but you are not responsible for the food of the other [the pig].

R. Jonah added the following comment:

The Holy One, blessed be He, knows that a dog's food is meagre, He therefore makes it retain its food in its stomach for three days. ${ }^{104}$

Since dogs did not eat much, feeding them was not considered to be an onerous responsibility.

In the same sugyah concerning the feeding of dogs, the Babylonian Rabbis added views that were most probably based on popular Babylonian practices.

100 In the parallel in Pesikta de-Rav Kahana, Vayehi Beshalah 1 (ed. Mandelbaum, pp. 17576), the Rabbi who was invited to Caesarea is R. Abbahu. For the motif of the dog who guards his owner, cf. also Thompson, Motif-Index, vol. 6, p. 218 (B524.1.4.1); p. 222 (B524.1.2.1); cf. Lieberman, Greek in Jewish Palestine, p. 126 n. 91.

101 War 7.180-85 (trans. H. St. J. Thackeray $[L C L]$, pp. 557-59). This technique of plant extraction is mentioned in additional sources, as well. See: Aelian, On Animals 14.27. It also is depicted in a manuscript from 512 CE. See R. T. Gunther (ed.), De materia medica, The Greek Herbal of Dioscurides, Englished by Joan Goodyer 1655 (New York, 1959), Pl. XII. Cf. also L. Y. Rahmani, 'Byzantine Solomon Eulogia Tokens in the British Museum', IEJ 49 (1999), pp. 100-01.

102 Cf. Matt. 15:26-27 (=Mark 7:27-28): 'And he answered, "It is not fair to take the children's bread and throw it to the dogs." She said, "Yes, Lord, yet even the dogs eat the crumbs that fall from their master's table." ' Cf. Pope, Song of Songs, pp. 212, 215, for this motif in ancient art; cf. also: Ant. 12.213. Tryphon, the court jester of the Egyptian king, mocked Joseph son of Tobias for having left many bones on his plate at the end of the feast. Joseph retorted: 'for dogs eat the bones together with the meat [...] but men eat the meat and throw the bones away' (trans. R. Marcus, $L C L$, p. 109) Cf. also: BT Taanit 11b, for dogs that received the meals of fasting Babylonian Rabbis.

103 Some things, obviously, were not eaten by dogs. See e.g. Lev. Rabbah 28:6 (ed. Margulies, p. 662).

104 For the view that food remains in the dog's intestines for three days, see: M Oholot 11:7; M Zavim 2:3. 
Thus, for example, R. Hamnuna notes that 'it is the way of the world to throw raw meat to a dog.' In answer to the Talmud's question as to the amount of meat to be given to the dog, R. Mari states: 'As the measure of its ear', that obviously is not a large quantity. R. Mari even adds: 'and the stick afterwards!' In other words, after the meat has been thrown to the dog, he is to be beaten, so that he will not be accustomed to ask for food from the one throwing the meat; this obviously does not refer to a house dog or a pet. The Talmud then specifies: 'this applies in the field, but not in the city, because it will come to follow him.' These Babylonian Rabbis even assert that wild dogs in the fields are to be fed. In the city, this custom could become bothersome; at any rate, city dogs could reasonably be expected to fend for themselves, without any special help. ${ }^{105}$ The sugyah is concluded with a popular maxim cited by $\mathrm{R}$. Papa: 'None are poorer than a dog [since it eats little], and none wealthier than a pig [since it is omnivorous].'

The ability of town or city dogs to find food is not always considered an advantage. Thus, Miqsat Ma'ase Ha-Torah of the Dead Sea Sect prescribes:

And one must not let dogs enter the holy camp, since they may eat some of the bones of the sanctuary while the flesh is (still) on them. For Jerusalem is the camp of holiness, and is the place which He has chosen from among all the tribes of Israel. For Jerusalem is the capital of the camps of Israel. ${ }^{106}$

The sect members feared that the tendency of dogs to search for bones would be an affront to anything that had been devoted to the Temple, ${ }^{107}$ and therefore enacted that dogs were not to be allowed into the city. Like, however, their other statements concerning Jerusalem and the Temple, this demand

105 There were many possibilities for dogs to find food in the city. The traditions frequently describe the bloodthirstiness of wild urban dogs. Thus e.g. PT Terumot 8:3 (45[c]): 'It happened that a butcher in Sepphoris provided Israelites with improperly slaughtered meat. Once he was drinking wine on a Sabbath eve, climbed to the roof, and fell to his death, and the dogs licked his blood.' See also M Hullin 7:6 and our discussion below, 'Bad Dogs'. In wartime, corpses were thrown to the dogs. See War 6.367.

106 See E. Qimron and J. Strugnell, Discoveries in the Judaean Desert, X: Qumran Cave 4, V, Miqsat Ma'ase Ha-Torah (Oxford, 1994), pp. 52-53. See also E. Qimron, 'Chickens in the Temple Scroll (11QTc)', Tarbiz 64 (1995), pp. 473-75 (in Hebrew), who asserts that this prohibition probably also was set forth in the Temple Scroll.

107 Cf. Matt. 7:6: 'Do not give dogs what is holy; and do not throw your pearls before swine, lest they trample them under foot and turn to attack you.' Cf. Didache 9:5d, with the beginning of the verse, in reference to the prohibition against the non-baptised partaking of the Eucharist; the dog is naturally given a symbolic interpretation. See the lengthy discussion in $\mathrm{H}$. van de Sandt, " "Do Not Give What Is Holy to the Dogs" (DID 9:5D and Matt 7:6A): The Eucharist Food of the Didache in Its Jewish Purity Setting', Vigiliae Christianae 56 (2002), pp. 223-46, who argues that the tradition in the Didache preceded that in the New Testament. He also attempts to connect these traditions to the halachah in M Temurah 6:5 that 'animal-offerings may not be redeemed in order to give them as food to the dogs' in the sense that the mishnah teaches that animal-offerings, even with defects that invalidate them for Temple use, do not entirely lose their sacred standing to the extent that they may be regarded as completely hullin (unconsecrated objects): 'to give them as food to the dogs'. According to van de Sandt, the traditions in both the New Testament and the Didache are reflective of this Jewish approach. See also: PT Maaser Sheni 2:5 (53[c]); BT Bekhorot 15a; BT Temurah 17b; 31a; 33a-b; BT Shevuot 11b, and more. For additional literature on the verse in Matthew, see van de Sandt, p. 233 n. 23. 
most probably remained theoretical. ${ }^{108}$ Thus, M Bava Kamma 7:7 establishes that 'fowls may not be raised in Jerusalem, because of the hallowed things', but there is no prohibition against raising dogs in this city. ${ }^{109}$ It has been asked why the Rabbis were strict regarding fowl, but not dogs; possibly, the danger of dogs roaming throughout Jerusalem was less serious than that of fowl pecking at refuse, and the actions of dogs, at least some of whom had owners, did not require Rabbinic stringency in this respect.

Do the sources cited above attest to dogs as pets? ${ }^{110}$ Even if the answer is positive, it is improbable that dogs in Jewish society were the objects of the same degree of affection as they received in the Graeco-Roman world or the Persian world. Sheepdogs and guard dogs may very well have turned into pets, or their masters and the members of their households may have treated them as such, obviously when the dogs were not occupied with their more formal duties, but it would be extremely difficult to prove such relationships. The tradition that speaks of 'a person naming his dog after his father' could possibly reflect the practice of the upper social strata in the Land of Israel and in Babylonia. ${ }^{111}$ It is also difficult to determine if children kept dogs as pets and played with them in all sorts of ways, as did their young counterparts in the non-Jewish world; ${ }^{112}$ in any event, the extant material regarding children's play in antiquity is sparse, and the material that we possess cannot

108 Qimron links this to the writ of privileges that the Jews received from Antiochus III in 198 BCE, concerning the prohibition against bringing impure meat to Jerusalem (Ant. $12.254 \mathrm{ff}$.), in which dogs are not mentioned.

109 It was feared that they would burrow through the refuse and bring a dead insect, thereby imparting impurity to the meat of sacrifices. This same mishnah mentions the raising of dogs in general; see our discussion, below. On 'dangers to health' in Jerusalem caused by animals, see the extensive discussion of E. Dvorjetski, 'Public Health in Jerusalem during the Second Temple Period', in Z. Amar, E. Lev and J. Schwartz (eds), Medicine in Jerusalem throughout the Ages (Tel Aviv, 1999), pp. 17-18 (in Hebrew).

110 Cf. Lewysohn, Zoologie, pp. 86-87, on BT Ketubot 61b: '[a woman] who plays with small dogs'. See above, n. 48 and the references there. The intent is not to actual dogs, but to game pieces for board games and gambling. See Brewer, Clark and Phillips, Dogs in Antiquity, p. 33, Fig. 3.8, for the depiction of hounds on gaming pieces from ancient Egypt.

111 See Mekhilta, Masekhta de-Ba-Hodesh, Yitro 6 (ed. Horovitz-Rabin, p. 226): 'A philosopher asked Rabban Gamaliel [...] but idolatry possesses power that is to be envied. He said to him: If a person calls his dog by the name of his father, and when he takes a vow, he does so [with the formula] "By the life of this dog", of whom should he be jealous, of the son or of the dog?' See Lieberman, Greek in Jewish Palestine, pp. 126-27. Rabban Gamaliel is mocking the Greek Sophist, but this does not rule out the depiction of the dog as a pet. The question is whether this background also reflects the reality of Jewish society. See also the parallel: BT Avodah Zarah 54b: 'To a human king who had a son, and the son reared a dog to which he attached his father's name, so that whenever he took an oath he exclaimed, "By the life of this dog, my father!" When the king hears of it, with whom is he angry — his son or the dog? Surely he is angry with his son!' As was noted above, the 'king' traditions probably also reflect high society; does this, too, refer to Jewish society?

112 Thus e.g. the Christian pilgrim Theodosius (sixth century) tells of seven Christian brothers, during the anti-Christian persecutions by the emperor Decius, who hid in a cave in Ephesus, together with 'catalus Viricanus, ad pedes eorum' (with the little dog Viricanus at their feet): Theodosii, De Situ Terrae Sanctae, Itineraria et Alia Geographica, CCSL 175 (Turnholt, 1965), 26 (p. 123). On this source see: O. Limor, Holy Land Travels: Christian Pilgrims in Late Antiquity (Jerusalem, 1998), p. 190 n. 109 (in Hebrew). 
always be easily understood. ${ }^{113}$ It may reasonably be assumed, however, that if dogs were kept in the house, and despite the guard duties that were sometimes imposed upon them, preventive measures were sometimes taken against possible violence, such as the extraction of these animals' teeth or claws. ${ }^{114}$

\section{5. 'Bad Dogs'}

As was shown above, despite the utility of dogs, something of the negative approach toward dogs characteristic of the Biblical period remained in the Second Temple period and in the time of the Mishnah and Talmud. This wary attitude ensued in no small measure from the natural violent streak that could come to the fore even in a house or courtyard dog, and would obviously be exhibited by wild dogs that continued to roam through the streets of a settlement, or beyond its bounds. ${ }^{115}$ The sources that mention such dogs describe them as bloodthirsty ${ }^{116}$ and lustful. ${ }^{117}$

Most of these complaints, however, were not directed against wild dogs, but were addressed to those who raised dogs but without supervision. ${ }^{118}$ We have

113 See e.g. Schwartz, "A Child's Cart", (n. 28 above).

114 BT Shabbat 63a-b; see also BT Bava Kamma 83a.

115 See War 3.192, on the emissaries who left Jotapata 'disguised' as the wild dogs who prowled about outside the city walls.

116 See e.g. Pesikta de-Rav Kahana, Zekhor 8 (pp. 46-47): “"Amalek” [Deut. 25:17]—am leka nation $[u m m a h]$ that came to lick $[l a-l u k]$ from the manna of Israel, like a dog. R. Levi, in the name of R. Simeon ben Halafta, To what is this comparable? To a fly that is greedy for a wound. Thus was Amalek greedy to get at Israel, like a dog.' See also the parallel: Tanhuma, ed. Buber, Tetze 12 (fol. 20b). Cf. Luke 16:21. Sometimes the vicious behaviour of such dogs is the result of a harsh reality, such as war. See e.g. War 4.324, 5.526.

117 See BT Sanhedrin 108b. A Babylonian baraita relates that the dog was incapable of observing the prohibition against sexual relations (with other dogs) in Noah's Ark, and was therefore punished to be 'tied' while engaging in the sexual act. Cf. Thompson, Motif-Index, vol. 6, p. 223, motif A2496.1: 'why dogs get stuck in copulation'. Cf. also the tradition in BT Yebamot 59b, brought by R. Dimi upon his return to Babylonia: 'It once happened that a young woman in Haitalu [=Aitalu=Ilut, near Sepphoris] was sweeping the floor, and a kufri dog had intercourse with her from behind.' See below, 'Appendix', for the identification of the kufri dog. The imagery of the licentious dog also featured prominently in Christian attacks against the pagans, who were charged with all manner of sexual deviations. For a detailed discussion, see B. L. Visotzky, 'Overturning the Lamp', JJS 38 (1987), pp. 72-80. See also Rev. 22:15: 'Outside are the dogs and sorcerers and fornicators and murderers and idolaters, and every one comes and practises falsehood.' The 'dogs' here are to be understood as those who engage in sodomy. See: J. M. Ford, The Anchor Bible: Revelation (Garden City, NY, 1975), pp. 347-48; R. M. Grant, Early Christians and Animals (London and New York, 1999), pp. 6-7. Philonenko argues from this verse for the author of Revelation having knowledge of the halachah in Miqsat Ma'ase ha-Torah mentioned above, that dogs are not to be brought to Jerusalem. In his view, that halachah does not refer to actual dogs, but rather to human beings, and the 'dog' of Miqsat Ma'ase ha-Torah is symbolic, as in Revelation. See M. Philonenko, 'Dehors les chiens' (Apocalypse 22.16 et 4QMMT B 58-62)', New Testament Studies 43 (1997), pp. 445-50. Despite our certainty that this is the correct interpretation of Revelation, it would not seem that there is any reason to deviate from the simple meaning of the halachah in 4QMMT (see our discussion, above).

118 See Gen. Rabbah 77:3 (ed. Theodor-Albeck, pp. 913-14) for the king who owned an agriyon (wild) dog and an imiron (tame) lion, and who sought to 'toughen up' his son. This, of course, does not attest to the usual situation in Jewish society, not even in the wealthy classes. It is doubtful whether the simple folk, that is, anyone not a 'king', kept wild, untamed dogs in their house; even the tasks that demanded of the dog aggressiveness also required discipline. See also Cant. Rabbah 3:5. Some people allowed their dogs to roam freely in the public domain, and these dogs 
already mentioned the injunction in $\mathrm{M}$ Bava Kamma 7:7 regarding guard dogs, that 'a person may not raise a dog unless it is chained.' The mishnah suggests the taking of general precautionary measures. PT Bava Kamma (7:7 [6(a)]) and several commentators interpreted the mishnah as referring to a 'bad dog'. ${ }^{119}$ The passage in the Palestinian Talmud reads:

R. Yossi said in the name of R. Haninah: Scripture says of anyone who raises a bad dog within his property: 'He who withholds kindness from a friend ...' [Job 6:14].

Especially intriguing is the fact that the sources that depict the bad house dogs do not indicate viciousness or wild behaviour, they rather are concerned with the regular actions of dogs, activities that are not intrinsically harmful. Thus, for example, the Palestinian sage R. Dostai of Biri ${ }^{120}$ tells in BT Bava Kamma 83a of a dog's barking that caused a woman to miscarry a foetus in whose birth would have been completed the number of souls in Israel necessary for the Divine Presence to rest upon it:

R. Dostai of Bira expounded: 'And when it halted, he would say: "Return, O Lord, You who are Israel's myriads of thousands!" [Num. 10:36] - to teach you that the Divine Presence does not rest upon Israel if they are less than two thousand and two myriad. [The Israelites] were lacking one, and here was among them a pregnant woman thus capable of completing [the number], but a dog barked and she miscarried. Consequently, this [dog] was responsible for the Divine Presence departing from Israel.

This exposition does not explicitly speak of a house dog, but the continuation of the tradition definitely refers to a dog of this type, from which we may conclude that the barking dog in the beginning of this tradition, as well, was not a wild dog, but one that was supposed to be domesticated:

A certain woman went to bake in a certain house, in which a dog barked. The owner told her: 'Do not be afraid, we have removed its teeth.' She replied: 'Take your favours and cast them on the thorns; it [the foetus] has already moved' [from its place, i.e. she has already miscarried]. ${ }^{121}$

All that the dog did was bark. According to his owner, the dog could not have harmed the woman in any way, but its very barking, and possibly the fact that it was not chained (according to the interpretation of some commenta-

caused a great deal of damage. See BT Moed Katan 17a, for the dog in Babylonia that would regularly eat the Rabbis' shoes. Because of such dogs, the Jewish folk tradition declares: 'Good pups will not come from a bad dog' (Seder Olam Rabbah 25).

119 See e.g. Tosefot Yom Tov ad loc., that mentions the addition to the text of the Mishnah of 'bad dog' in the Shulhan Arukh and in the Tur. Cf. the commentary by Rashi on M Bava Kamma ad loc.: 'Because it bites, barks, and causes a woman to miscarry from fear of it.'

120 Not much is known about this sage, who apparently was connected to Biri, near Safed. See Ch. Albeck, Introduction to the Talmud Babli and Yerushalmi (Jerusalem, 1975), p. 232 (in Hebrew).

121 And with minor changes, in BT Shabbat 63a-b: 'A certain woman entered her house to bake. The dog barked at her, and her foetus moved [from its place]. The householder told her: "Do not be afraid, for its fangs and its claws have been removed." She replied: "Take your favours and cast them on the thorns; the foetus has already moved [i.e. she has already miscarried]".' 
tors, and as is indicated by the plain meaning of the sugyah), ${ }^{122}$ alarmed the woman and caused her to miscarry. The dog was not dangerous, but nevertheless caused serious damage, which could explain some of the negative approaches to dogs and what turned them into 'bad dogs', even though they were not, in reality, so ill-behaved.

Especially illuminating is the baraita in BT Bava Kamma 15b, in the name of R. Nathan, that compares the raising of a bad dog within one's house to placing a shaky ladder there:

For it was taught: R. Nathan says: Whence [do we learn] that a person should not raise a bad dog in his house, and should not place a shaky ladder therein? Scripture teaches: 'so that you do not bring bloodguilt on your house' [Deut. $22: 8] .^{123}$

The householder and the members of the household most likely knew how to deal with the defective ladder or the unchained barking dog. Others, however, who might not have expected such surprises, would suffer.

There are two diametrically opposed approaches regarding the raising of dogs in the house or in the courtyard. R. Simeon ben Eleazar forbids raising dogs within a regular settlement, but does permit raising them in a border town, where their potential usefulness for security apparently overweighed their potential for causing damage within the house. ${ }^{124}$ Even in border settlements, R. Simeon ben Eleazar insisted that they be restrained by iron chains during the day, and let free only at night. R. Eleazar, however, was repelled by dogs in any form, and ventured the opinion that 'the one who raises dogs is tantamount to the one who raises pigs.' ${ }^{125} \mathrm{He}$ also asserted that 'the one who keeps bees is tantamount to the one who raises dogs', thus clearly indi-

122 See e.g. Rashi on Bava Kamma 83a, s.v. 'Shekili Tivutikh'.

123 See also: BT Bava Kamma 15b,46a; BT Ketubot 41b; Midrash Tannaim on Deut. 22:8.

124 T Bava Kamma 8:17 (ed. Lieberman, pp. 40-41). This Tanna actually permitted raising of $k$ fri dogs in the house, because they 'clean the house', but see the discussion on this point, below. It is doubtful whether the kufri dog was even a dog. See also: BT Bava Kamma 83a.

125 T Bava Kamma 8:17. See also T Bava Kamma 8:15 (ed. Lieberman, p. 40): 'If a person inherited pigs and dogs, he is not required to sell them all together, rather he sells one at a time.' It is difficult to determine whether the Tosefta refers to a case in which a person inherited either pigs or dogs (and M Bava Kamma 7:7 mentions dogs and pigs separately), or that he inherited both dogs and pigs, and therefore the heir must be rid of them. Either way, there is a patent connection here between pigs and dogs, according to the view of R. Eliezer. The unit in BT Bava Kamma 83a speaks of a convert who inherited the animals, but the word ger is omitted from MS. Hamburg. Dogs and pigs appear together in the same context in a number of additional sources. Thus in Mekhilta de-Rabbi Simeon ben Yohai 12:19 (p. 23): 'If debris fell on hametz [leavened matter], or if it fell into a pit, into a cellar, or into a cask: if (the) dogs and pigs are able to search for it and bring it out ...' See also BT Shabbat 155b: 'Food may be placed before a dog [on the Sabbath], but food may not be placed before a pig. What is the difference between them? You are responsible for the food of this one [the dog], but not for the food of the other one [the pig].' See also T Berakhot 2:16 (ed. Lieberman, p. 9): 'One need withdraw [to pray] only from [excrement] and from that of dogs.' And so too in PT Berakhot 3:5 (6[d]). BT Berakhot 25a adds the excrement of pigs, fowl, and the filth of a dung heap that gives off a bad smell. This seemingly links dogs and pigs once again, but hazirim (pigs) does not appear in the manuscripts. For the connection between these two animals, cf. Matt. 7:6; cf. also S. Shaked, Amulets and Magic Bowls: Aramaic Incantations of Late Antiquity (Jerusalem, 1985), p. 210. For a dog and an ass, see PT Avodah Zarah 3:2 (42[d]); BT Sanhedrin 63b. 
cating his apprehension that even domesticated dogs regularly cause trouble and damage. ${ }^{126}$

Unruly and wild dogs that roamed about in public places always posed a danger of biting. ${ }^{127}$ Thus, the midrash tells of a father who was strolling about in the marketplace with his son on his shoulders. The parent became angry with his child, and as soon as he put him on the ground, a dog came and bit him. ${ }^{128}$ Dogs roaming free bit both livestock and humans. ${ }^{129}$ It would seem that there were many rabid dogs, and Talmudic traditions describe the causes of rabies, remedies for anyone who contracted this disease, and also the characteristics of sick dogs, so as to avoid contact with them. Thus, M Yoma 8:6 portrays a disagreement between the Rabbis and R. Mattiah ben Heresh concerning the permissibility of feeding to a person who had been bitten by a mad dog the lobe of the dog's liver on Yom Kippur (and, apparently, all the days of the year). ${ }^{130}$ The Rabbis were of the opinion that this was, at best, a folk medicine and would not be effective, and therefore should not be given to anyone on Yom Kippur (or any other time), while R. Mattiah permitted this, whether he regarded it to be a remedy, or was skeptical of its healing qualities:

If a person was bitten by a mad dog, he may not be given the lobe of its liver to eat; but R. Mattiah ben Heresh permits this. ${ }^{131}$

The distinguishing signs of the mad dog are given in PT Yoma 8:5 (45[b]):

The signs of the mad dog: its mouth is open, its spittle runs down, its ears dangle, its tail is between its two thighs, it walks to the sides, and other dogs bark at it. According to another opinion, it, too, barks, but makes no sound. ${ }^{132}$

Not only is this description remarkably accurate, but it also enables us to understand otherwise puzzling midrashim. ${ }^{133}$ Thus, for example, we read the following in Shir ha-Shirim Zuta 6:6 (ed. Buber, fol. 17a):

The wicked are compared to dogs that are of no benefit, as it is said, 'They are all

126 T Bava Batra 1:9 (ed. Lieberman, p. 131). The Tanna Kamma (first opinion) maintains that 'bees are to be kept at a distance of fifty cubits from the city, so that they would not sting people.'

127 Over the course of time, Jews were held to be afraid of dog bites, and this motif was used to mock them. Thus, in the fifteenth century, Juan de Trasmiera wrote a satirical play ridiculing the Jewish community in Alba de Tormes, Spain, for its presumably having sued a dog that had bitten some members of the community. The dog was sentenced to death by hanging, but it freed itself at the time of the execution, and attacked the spectators. See Encyclopaedia Judaica, vol. 2, col. 518, s.v. 'Alba de Tormes'.

128 Pesikta de-Rav Kahana, Zekhor (ed. Mandelbaum, p. 35). The tradition appears only in MS. Safed.

129 T Hullin 3(4):19 (ed. Zuckermandel, p. 505). A beast that was bitten by a wild dog was permitted in regard to the prohibition of terefah, but was forbidden because of the threat to life its consumption entailed. For the harm inflicted on humans, see below.

130 See Menache, 'Dogs in Classical Tradition'.

131 Our interpretation follows that of Ch. Albeck, The Mishnah, Moed (Jerusalem and Tel Aviv, 1959), p. 246. Cf. also idem, 'Supplements and Additions', p. 472 (in Hebrew). For the general use of dog liver, see Rosner, Preuss, pp. 195-96. Cf. also Brewer, Clark and Phillips, Dogs in Antiquity, p. 44. This medicine was also known in ancient Egypt.

132 And with minor changes, in BT Yoma 83b. Cf. also War 6.196.

133 See Lieberman, Hellenism in Greek Palestine (New York, 1962), p. 189 n. 68, and the references there. 
dumb dogs that cannot bark' [Isa. 56:10]: just as this dog [bites] a person, [and] he seeks from it a hair [to heal his wound], and does not succeed. Therefore, they were compared to dogs, for they possess [i.e. have performed] neither good deed nor commandment. ${ }^{134}$

This tradition is connected to the signs of the mad dog, especially that it 'barks, but makes no sound.' The Rabbis wanted to show that that no benefit is to be had from such a dog, and this especially includes the common folk remedy of pulling some hairs from its tail and applying them to the place of a dog-bite, a popular remedy in antiquity for such a bite by a rabid dog. ${ }^{135}$

The causes of rabies were also the subject of a disagreement. Interestingly, the two Rabbis who are also cited by the Palestinian Talmud ad loc. (Yoma 8:5 [45(b)]) are the Babylonians Rav and Samuel, and the main discussion of this point is conducted by Babylonians, who apparently believed in magical powers that could aid in healing the sufferer. The Palestinian Rabbis were much more pessimistic regarding the probability of being cured, even with the help of magical powers. Thus, we find in the PT, regarding the causes of the dog's illness:

Rav and Samuel: One said: A spirit of madness enters it; and the other said: A women engages in sorcery and tests her success (in magic) on it. ${ }^{136}$

Both causes were known in antiquity. Regarding the first, Jews, as well, believed that evil spirits harmed both animals and humans. ${ }^{137}$ As for the second cause, women's participation in the black arts and their use of various beasts and animals to these ends are known. It should be stressed that nothing in this sugyah implies that these were Jewish women. ${ }^{138}$ The parallel in BT (Yoma 83b) explains that these two views differ regarding the manner in which such a dog can be killed. According to the one who maintains that an evil spirit has entered the dog, ${ }^{139}$ one should not draw close to the animal in order to dispatch it, lest the evil spirit harm the attacker; such a precaution is not necessary according to the view that the dog has been 'bewitched'.

In contrast to the optimism of the Babylonians, the Palestinian sages did not rate highly the chances of survival for someone who had been bitten by a rabid dog. The continuation of the sugyah in the PT tells of the German slave

\footnotetext{
134 See also Aggadat Shir ha-Shirim, p. 40, 1.1192 (ed. Schechter). The text is as quoted in Yalkut ha-Meiri on Isa. 56:10, and is cited by Lieberman, Hellenism in Greek Palestine, pp. 18889.

135 Based on Lieberman, loc. cit. For the rubbing of ashes from the hair under the dog's tail into the wound caused by the bite, see Plin. Hist. Nat. xxix.32.98.

136 BT Yoma 83b: 'Rav said: Witches sport with it; and Samuel said: An evil spirit rests upon it.'

137 J. Trachtenberg, Jewish Magic and Superstition: A Study in Folk Religion (New York, 1970), p. 199. Cf. also J. Naveh and S. Shaked, Magic Spells and Formulae: Aramaic Incantations of Late Antiquity (Jerusalem, 1993), p. 203. The 'evil spirits' mentioned in an amulet that was written to protect a bride include 'the spirit of a fox'.

138 T. Ilan, Jewish Women in Graeco-Roman Palestine: An Inquiry into Image and Status (Tübingen, 1995), pp. 221-25. For witches and dogs in the Roman world, see Burris, 'The Place of the Dog', pp. 38-39.

139 After this, it does not take a great stretch of the imagination to turn the dog into a demon, as occurred in the medieval period. See Trachtenberg, Jewish Magic and Superstition, p. 27.
} 
of R. Judah Nesiah who was bitten by a mad dog, and despite his eating the lobe of the dog's liver, the possible cure mentioned in the mishnah cited above, he was not cured. Based on this episode, the Talmud declares: 'Let no one tell you that he was bitten by a mad dog and lived.' ${ }^{140}$ According to the discussion in the BT, anyone who rubbed against such a dog in Babylonia was advised to shed his clothes and flee. In the continuation of the discussion (BT Yoma $84 a$ ), it was prescribed that anyone so bitten was to drink water only from a tube, lest when he drinks from a spring or a pool he see the shadow of the dog that bit him. ${ }^{141}$

\section{The Dog as Symbol}

The dog's unique characteristics (and, at times, its ordinary traits, as well) would sometimes be used as symbols. Despite the utility of the dog, and despite the close relationship that was formed on occasion between dogs and their masters, these metaphors are almost invariably negative, even when the final meaning of the symbol is positive. Thus, for example, the wealthy Jerusalemite Ben Kalba Savua is so named 'for anyone who enters his house as hungry as a $\operatorname{dog}\left[\right.$ kelev] leaves full [sabe'a]. ${ }^{.142}$ The imagery of the hungry dog indicates an animal so ravenous for food that his hunger drives him mad. ${ }^{143}$ The appellation 'Savua' was therefore added to Ben Kalba's name: he filled up people who were as hungry as a dog, but he himself had no connection to dogs, and the image of the dog remained negative. ${ }^{144}$

A similar approach is to be found in a baraita in BT Kiddushin 40b, with the exaggerated claim: 'Our masters taught: One who eats in the marketplace is comparable to a dog; and some say that he is unfit to testify.' R. Idi bar Avin adds: 'The halachah agrees with the latter view.' The imagery is of a dog that wanders about the marketplace and burrows through the garbage in search of food, or who steals from shopkeepers or customers. The Talmud establishes that such behaviour, by someone who is incapable of maintaining his honour, and acts in a shameful manner, that is, like a dog, disqualifies him from giving testimony. ${ }^{145}$

Interestingly, it was not the dog's worst characteristics - aggressiveness and

140 See also PT Berakhot 8:6 (12[b]).

141 See Lieberman, Hellenism in Greek Palestine, p. 190. Lieberman has already shown that this and similar views were widespread among non-Jews, albeit without finding parallels in the Graeco-Roman literature.

142 BT Gittin 56a; Avot de-Rabbi Nathan, Version A, 6 (ed. Schechter, p. 32). Cf. BT Ketubot $62 \mathrm{~b}-63 \mathrm{a}$.

143 War 6.196: 'Gaping with hunger, like mad dogs' (trans. H. St. J. Thackeray, LCL, p. 433).

144 Cf. PT Taanit 4:2 (68[a]): 'Ben Kalba Savua from Caleb'. This is an apparently more successful attempt to explain the name. On the other hand, the name Caleb son of Jephunneh is probably derived from kelev; according to one view, this is an abbreviation of kelev ha-El [the dog of God]', in the sense of His faithful servant. See J. Liver, s.v. 'Kelev', Enziklopedyah Mikra'it (Encyclopaedia Biblica), vol. 4, col.109.

145 See also Tosafot, BT Kiddushin 40b, s.v. 'Ve-Yesh Omrim af Pasul le-Edut', with sources from the Palestinian Talmud attesting to people who would regularly eat in the marketplaces, with no opprobrium attached to this. The Palestinian norms in this matter seemingly differed from those in Babylonian society. 
violence - that were translated into negative motifs, ${ }^{146}$ but rather the less dangerous traits, such as insolence, brazenness, and lustfulness, that provided many unflattering metaphors for negative conduct among humans as well. Thus, for example, Ben Sira already asserted that 'the unruly wife will be thought of as a bitch.' ${ }^{147}$ A stubborn (and possibly independent) woman is considered to be as shameless and insolent as a dog. Josephus attacks Apion, claiming that he had the heart of an ass and the insolence of a dog. ${ }^{148}$ The end of Tractate Sotah (M 9:15) warns that 'the face of this generation is as the face of a dog, and the son will not be put to shame by his father', but rather acts insolently toward his parent, and shows the latter no respect. ${ }^{149}$

For these reasons, we can understand why the term 'dog' was generally derogatory and it is apparently not coincidental that the term 'consumption by Gentiles' appears in proximity to 'consumption by dogs', that attests to the standing of both non-Jews and dogs. ${ }^{150}$ Or, R. Johanan says, regarding someone interred in a 'nagar' burial (with the corpse placed in an upright position): '[Even] dogs are not buried in such a manner' ${ }^{151}$ — to be buried in a fashion inferior to that of dogs is considered to be the ultimate humiliation.

Being called a dog was undoubtedly insulting, and it is not surprising that Jews sometimes called idolatry by the name of a dog, ${ }^{152}$ or that a Rabbinic

\footnotetext{
146 For an enormous demon in the form of a dog, see Testament of Solomon, chaps. 10, 11. The demon told King Solomon that he especially deceives those who follow his star; in the end, the demon agrees to aid Solomon. See also ibid., 18:1: the heavenly bodies appear before Solomon with canine heads. Sources that depict a dog as a demon are seemingly related to canine violence, but it is more plausible that these traditions are Christian, and not Jewish. For the background of the Testament of Solomon, see D. C. Duling, 'Testament of Solomon', in J. H. Charlesworth, The Old Testament Pseudepigrapha, vol. 1 (Garden City, NY, 1983), pp. 935-59.

147 Sirach 26:25 (ed. Segal, p. 160; trans. P. W. Skehan, Anchor Bible 39 [New York, 1987], p. $345)$ For the evil woman and the good woman in Sirach, see Ilan, Jewish Women in Graeco-Roman Palestine, pp. 57-58. Cf. also W. C. Trenchard, Ben Sira's View on Women: A Literary Analysis (Chico, CA, 1982), p. 12, who asserts that this verse is not part of the original text of Ben Sira, but the source of the sentiment was probably ancient, and might possibly have been derived from a source contemporary with Ben Sira.

148 Against Apion 2.85. See also: Mueller, Des Flavius Josephus Schrift, p. 262. For dogs and asses, see: PT Avodah Zarah 3:2 (42[d]); BT Sanhedrin 63b.

149 See also: PT Sotah 9:16 (23[b]); BT Sotah 49b.

150 See e.g.: T Yom Tov 2:6 (ed. Lieberman, p.287) and parallel in Mekhilta de-Rabbi Simeon ben Yohai 16 [ed. Epstein, p. 21]); T Hullin 2:15 (ed. Zuckermandel, p. 502); 5(6):2 (p. 507); 6:4 (p. 507); 9:2 (p. 510); T Menahot 10:29 (p. 529); Sifra, Aharei Mot 11:5; Sifra, Emor 8:7. Cf. Matt. 15:26-27 (=Mark 7:27-28), that implies that Jews called Gentiles 'dogs.' The Christians also applied this epithet to the Jews; see e.g. Philippians 3:2.

151 PT Bava Batra 2:2 (15[c]); see also: M Bava Batra 2:2. For the manner in which dogs were laid to rest in Ashkelon, see Wapnish and Hesse, 'Pampered Pooches', pp. 55-80, esp. pp. 58-59. Some dogs were buried separately, in fairly shallow graves. These dogs were laid on their side, that proves that they were not interred in a nagar burial.

152 T Avodah Zarah 6:4 (ed. Zuckermandel, p. 469) (and parallels): 'All the places that were given names complimentary to idolatry are given insulting appellations. A place that is called pene melekh [the face of the king] is to be called pene kelev [the face of a dog]'; thus in Ms. Vienna and in the printed editions. MS. Erfurt replaces 'pene melekh' with 'pene elah [the face of a goddess].' For this tradition, see Lieberman, Greek in Jewish Palestine, pp. 125-26. In Midrash Tannaim on Deut., 12(26):3 (ed. Hoffmann, p. 60): 'If you heard that its name is the face of Baal, call it the face of a dog.' For the connection between pene-baal (the face of Baal) and the god Phanebal that appears on city coins of Ashkelon (that has a canine connection, as we have
} 
tradition labels the sons of Haman 'dogs'. ${ }^{153}$ Another late tradition tells that Turnus Rufus became angry at R. Akiva, who related to him that he had had a dream, in which he saw two dogs. One was called Rufus, and the other Rufina, after Turnus Rufus and his wife. Turnus Rufus, who interpreted the tradtion as an insult was naturally upset. ${ }^{154}$ Likewise, R. Eliezer ben Hyrcanus spoke bluntly of 'the dog of the High Priest', plainly referring to the High Priest himself. ${ }^{155} \mathrm{R}$. Yannai applied a similar appellation to a householder who invited him but, it transpired, was an ignoramus. ${ }^{156}$

\section{Appendix: 'Kufri'}

The last dog that we shall discuss is ha-kelev ha-kufri, i.e. the kufri-dog, even though there is no certainty that this was an actual dog. Thus, for example, M Kilayim 1:6 rules that 'the wolf and the dog, ha-kelev ha-kufri and the fox [...] are kilayim [diverse kinds forbidden to breed with one another] to each other.' The sugyah in PT on this mishnah (PT Kilayim 1:6 [27(a)]) mentions a disagreement between the Rabbis and R. Meir. According to the Rabbis: '[The mating of] a dog with a kufri-dog does not constitute kilayim.' Since the mishnah specifically prohibited dog-wolf and kufri-dog-fox couplings, the Rabbis deduced that there was no problem with the mating of a dog and a kufridog, while R. Meir maintains that these are two different types of creatures: 'Although R. Meir states that a dog is a behemah [domesticated animal], he agrees that a kufri-dog is a hayah [wild beast]. Consequently, [the coupling of] a dog with a kufri-dog, according to R. Meir, constitutes kilayim.' Since R. Meir was of the opinion that the regular dog is a behemah, while the kufri is a hayah, the prohibition of kilayim applies to these disparate types. The Rabbis,

seen above), see E. Friedheim, 'Paganism and Pagan Rites in the Talmudic Literature: Historical Aspects', Ph.D. diss., Bar-Ilan University, 2000, pp. 177-80 (in Hebrew). See also Deut. Rabbah, Ve'ethanan (ed. Lieberman, pp. 62-63): 'R. Phinehas went to Bozrah and he was asked regarding the "market of the dog" (shuq kalba). And he said to them this faces Kedesh in the Galilee.' On this (difficult) tradition and its possible relation to paganism, see Lieberman, Deut. Rabbah, p. $63 \mathrm{n} .1$; see also p. 95. In contrast with the Jewish tradition, in the Hellenistic tradition the appellation of 'puppy' for a god was not necessarily regarded as insulting or derogatory. Cf. Mekhilta, Masekhta de-Ba-Hodesh, Yitro 6 (ed. Horovitz-Rabin, p. 226).

153 Midrash Tehillim 22:26 (ed. Buber, fol. 97b). Cf. J. Yahalom and M. Sokoloff, Jewish Palestinian Aramaic Poetry from Late Antiquity (Jerusalem, 1999), pp. 206-07 (in Hebrew), for a poem that is constructed as a dialogue between Haman and the wicked of the world and which compares Amalek to a dog. The ancestor who was 'crucified' is Agag (see the gloss by Yahalom and Sokoloff, p. 206, 1. 14).

154 Tanhuma (printed edition), Terumah 3: 'He [Turnus Rufus] immediately became angry. He said to him: You named your dog only after me and after my wife. You are condemned to death by the state.' In the continuation of the narrative, R. Akiva attempts to defend the choice of names, and argues that the emperor and empress are no different from dogs, but the traits that were mentioned in the tradition - such as eating and drinking, reproduction, and death - are not intrinsically negative.

155 T Kelim Bava Kamma 1:6 (ed. Lieberman, p. 569).

156 Lev. Rabbah 9:3 (ed. Margulies, pp. 176-78): 'He said to him: Say: A dog ate a piece of Yannai's bread.' And at the end of the tradition: 'He [R. Yannai] said to him [the householder]: You possess such a degree of derekh eretz [proper conduct], and I called you a dog.' 
on the other hand, classify both as hayot. ${ }^{157}$

Other traditions do draw a distinction between the regular dog and the kufri. Thus, as we have seen, R. Simeon ben Eleazar (T Bava Kamma 8:17) forbids raising dogs within a regular settlement, but permits such activity only in border towns. Despite this prohibition, R. Simeon rules, in this same halachah in the Tosefta: kufri-dogs, stone-martens, and cats, and monkeys, things [=animals] which clean the house, may be raised.' The opinion of R. Simeon regarding the kufri is most interesting, in light of the stringencies that he imposed on the raising of regular dogs. He even permits the sale of a kufri to non-Jews, despite the general ban against selling large or dangerous beasts to Gentiles, for fear of the damage that these creatures are liable to cause. ${ }^{158}$ R. Simeon's permissive opinion regarding the kufri is apparently to be understood in the background of the dangers posed by different rodents within the house, and the advantages to possessing the types of animals that were capable of cleansing the home of these pests. ${ }^{159}$

The identification of the kufri posed a problem for scholars. One view derived kufri from kefar (village), and understands this to be the dog of rural residents, ${ }^{160}$ but if so, why would a mere difference of locality between different types of dogs pose a difficulty regarding kilayim? According to the view of R. Simeon, we would also have difficulty in understanding the distinction between the kufri and those dogs that may be raised in border regions. According to another interpretation, this is a small dog that causes no harm to humans, but most likely posed a considerably greater threat to rodents within the house. ${ }^{161}$ This interpretation, as well, however does not help us to understand how this creature differs from a regular dog as regards the laws of kilayim.

Other scholars have questioned whether this 'kelev' is a dog at all. Thus, Yehudah Feliks identified the kufri with the jackal, but it could hardly be imagined that anyone would let such a beast into his or her home. ${ }^{162}$ Lewysohn argued that the strongest clue to the identification of this ani$\mathrm{mal}$ is to be found in the Mishnah (that forbids its breeding with a fox), and maintained that this prohibition specifically attests to the closeness of the two species, which explains why the kufri has relations with the dog and the fox. ${ }^{163}$ In this case, as well, we have difficulty in understanding what such a creature

157 Cf. T Kilayim 5:16 (ed. Lieberman, p. 223).

158 T. Avodah Zarah 2:3 (ed. Zuckermandel, p. 462) allows these animals to be sold to nonJews because they do not cause harm, but rather provide a service. T Shevi'it 5:9 (ed. Lieberman, p. 187) allows these sales to non-Jews on an incidental basis, but prohibits them as a regular source of earning a living. On the prohibition, in general, of selling certain beasts and animals to non-Jews, see T Avodah Zarah 2:2 (ed. Zuckermandel, p. 462).

159 On the other animals mentioned in these traditions that cleanse the house of rodents, see in detail J. Schwartz, 'Cats in Ancient Jewish Society', pp. 224-26.

160 Krauss, Talmudische Archaeologie, vol. 2, p. 121. Albeck, The Mishnah, Zeraim, p. 102.

161 Lieberman, Tosefta ki-Fshutah, Zera'im, pp. 552-53 n. 27; p. 652, also cites the interpretation by the Geonim that the kufri was a black dog, often found among the Arabs.

162 Y. Feliks, Mixed Sowing Breeding and Grafting: Kil'ayim I-II, Mishna, Tosephta and Jerusalem Talmud (Tel Aviv, 1967), p. 122 (in Hebrew)

163 See Lewysohn, Zoologie, p. 88. 
is doing in the home. ${ }^{164}$

Despite the difficulties with these proposed identifications, Feliks and Lewysohn are most probably correct that ha-kelev ha-kufri is not a regular dog. As we saw above in our discussion of the dog in Persian culture, the hedgehog, that excelled in ridding the house of pests, was thought by the Persians to be a type of dog. ${ }^{165}$ This animal is quite well-known, especially in Persian literature, but is also mentioned in the Roman literature. ${ }^{166}$ It therefore is highly likely that the hedgehog, that does such a fine job of pest control, is the kelev kufri.

Also, the confusion in the sources is understandable when we consider the similarity between all the creatures mentioned in relation to the kufri. The hedgehog, like the other creatures, also lives in Asia, and some types have long, sharp ears similar to those of dogs. ${ }^{167}$ Also, the fox, despite being from the canine family, is small and inhabits subterranean caves, in both respects resembling the hedgehog. It has a long snout and short legs (again, resembling the hedgehog), and with its tail wrapped around it while sleeping, looks like the hedgehog. In addition, at times the fox eats the same rodents that are the fare of the hedgehog. ${ }^{168}$ The confusion between all three species is therefore quite logical, especially since the Persian tradition thinks of the hedgehog as a dog. In the final analysis, we may conclude that ha-kelev ha-kufri of the Mishnah and other sources is not a true dog.

\section{Conclusion}

Jewish society's attitude towards the dog was complex. On one hand, there was the negative approach of the Biblical world and many of the surrounding lands. On the other hand, positive attitudes toward the dog developed in the Graeco-Roman world and in Persian culture. The change in these societies was in part functional, that is, greater emphasis was placed on the canine contribution to society, and sentimental, with emotional ties being forged between the dog and its master.

In Jewish society of the Second Temple, Mishnah and Talmud periods, the earlier, negative or ambivalent approaches were not totally absent, resulting in the 'bad dog' traditions, as well as those that used the dog as a negative symbol. However, the many services rendered by the dog could not be ignored, leading to the development of a positive attitude to different types of canines, such as sheepdogs and herding dogs, or guard dogs. At times, these dogs also became companions or pets, with bonds of affection growing between the dog and its master. The level of canine popularity in Jewish society, however, never reached the levels found in the Graeco-Roman or Persian worlds. We

\footnotetext{
164 See Philips and Wilcock, Xenephon and Arrian, p. 41, for the breeding of hounds with foxes.

165 See above, n. 47.

166 Varro Menippae 490.

167 H. Mendelsohn and Y. Yom Tov (eds), Plants and Animals of the Land of Israel (Tel Aviv, 1988), pp. 48-51. See also A. Leonard, Jr., 'Why a Hedgehog', in The Archaeology of Jordan (n. 12 above), pp. $310-16$ and the vast hedgehog literature cited there.

168 Idem, pp. 193-96.
} 
do not know of Rabbis who wrote books about their dogs or eulogised them upon their passing, as did the occasional Roman poet, nor have there been discovered canine motifs upon Jewish coffins, whether of adult or child, for example, expressing the close relationship between dog and human that might be found in the Graeco-Roman world. However, while the dog might not have been 'man's best friend' in Jewish society, it often did prove its friendship. 